LA--10987-PR

DE88 001940

\title{
Research by ESS Division for the Nevada Nuclear Waste Storage Investigations \\ January-June 1985
}

Compiled by

D. Vaniman

Contributors
D. Bish
S. Chipera
L. Brown
S. Levy
D. Broxton
P. Stringer
F. Byers
B. Travis
B. Carlos
D. Vaniman

\section{MASTER}

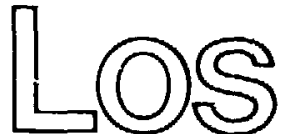

Alañல)

Los Alamos National Laboratory

Los Alamos, New Mexico 87545 


\section{CONTENTS}

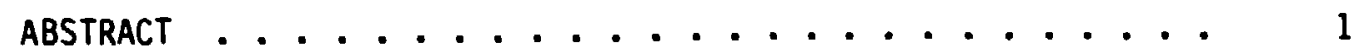

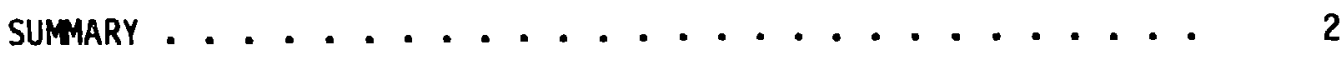

I. MINERALOGY AND PETROLOGY OF TUfF .............. 4

A. Internal Stratigraphy of the Topopan Spring Member . . . 5

B. Comparison of Clinoptilolite Compositions in the
Western and Eastern Parts of Yucca Mountain ..... 8

C. Mineral Stability and Definition of the Disturbed 12

D. Occurrence of Erionite at Yucca Mountain ....... 14

E. Studies of Sul fur Content Within the Topopan Spring Member.............. 14

F. X-Ray Diffraction Tecnniques for Tuff Analysis .... 17

G. Studies of Fault-Related Minerals and of Spring Deposits Around Yucca Mountain .......... 20

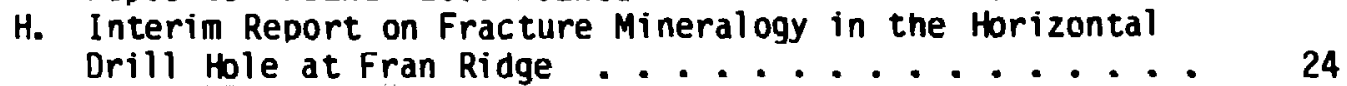

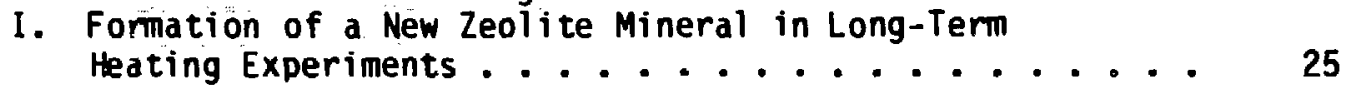

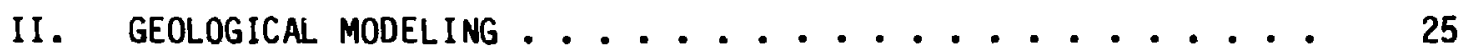

A. Recent Progress in Tracer-Diffusion Experiments for Fractured Rock .............. 25

B. Models of Tracer Diffusion in Topopan Spring and Calico Hills Materials ............

APPENDIX: GEOCHEMICAL RETARDATION IN THE HOST ROCK AND SURROUNDING UNITS - ANTICIPATED CONDITIONS ...... 41

REFERENCES ........................ 47

FIGURES

1. Location map of Yucca Mountain. ............ 3

2. Outcrop of the Topopan Spring xenolitnic zone in Black Glass Canyon. A large $(0.5 \mathrm{~m})$ rhyolite xenolith can be seen to the right of the hammer and above the apple.....

3. Compositions of clinoptilolites and heulandites at the top of the Topopan Spring Member basal vitrophyre. Data are from Drill Holes USW G-1, G-2, GU-3, G-4,

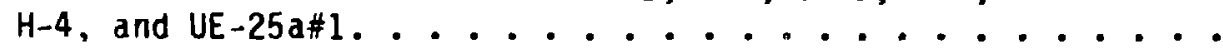

4. Comparison of the western (alkalic) and eastern (calcic) clinoptilolite series at Yucca Mountain.

Arrows and symbols within the ternary diagrams

al so show second-order variation with depth

(generally decreasing potassium content). 
5. X-ray diffraction pattern of erionite from a depth

of $1296 \mathrm{ft}(395 \mathrm{~m})$ in Drill Hole UE-25a\#1. Erionite

peaks are marked (Er); the remaining peaks are

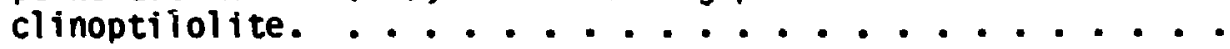

6. Observed $x$-ray diffraction pattern (upper) and

calculated pattern (lower) for a 50:50 weight

mixture of quartz and corundum. The lowermost

marks show thecalculated positions of all $K_{\alpha_{1}}$ and

$\mathrm{Ka}_{2}$ reflections for this mixture. ............

7. XRD comparison of features deposited from solution

along the sand-ramp slope at Fran Ridge (upper

pattern, FR6) and along the fault exposed

in Trench 17 (lower pattern, TR17). ..........

8. Original sample of sodium-exchanged (Na-rich)

Castle Creek clinoptilolite (lower pattern),

with structure resulting from $200^{\circ} \mathrm{C}$ heating for

one year superposed...................

9. Continuous outflow boundary tracer-concentration profiles at 5.1 days calculated for horizontally fractured tuff of Calico Hills (zeolitized).........

10. Continuous outflow boundary tracer-concentration profiles at 1.8 months calculated for horizontally fractured tuff of Calico Hills (zeolitized).........

11. Continuous outflow boundary tracer-concentration profiles at 1.8 months calculated for unfractured tuff of Calico Hills (zeolitized).............

12. Continuous outflow boundary tracer-concentration profiles at 1.5 days for vertically fractured devitrified Topopah Spring Member. ...........

13. Tracer-concentration profiles at 1.5 days within the fracture of Fig. 12. This figure represents a vertical section perpendicular to Fig. 12 and along the fracture at $x=0.052 \ldots . . . . . .$.

14. Tracer velocities at 1.5 days within the plane of the fracture in Fig. 13...............

15. Tracer-concentration profiles at 5.7 months calculated for diffusion in unfractured devitrified Topopah Spring material................

16. Tracer-concentration profiles at 5.7 months calculated for diffusion in unfractured zeolitized Calico Hills material. 
FIGURES (cont)

A-1a. The movement of a 10,000-yr pulse of technetium-99 for $v=4.5 \mathrm{~mm} / \mathrm{yr}, \ldots \ldots . . \ldots$

A-1b. The movement of a 10,000-yr pulse of technetium-99

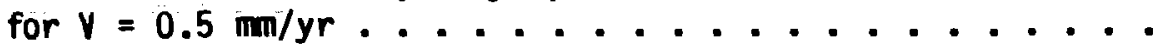

A-2a. Uranium-238 normalized mass flux entering water table for $v=4.5 \mathrm{~mm} / \mathrm{yr} \ldots \ldots . . . . . . .$.

A-2b. Uranium-23B normalized mass flux entering water table for $v=0.5 \mathrm{~mm} / \mathrm{yr} \ldots \ldots . . . . . . .$.

\section{TABLES}

I. Representative Clinoptilolite Compositions, Yucca Mountain, Nevada ..............

II. Concentration of Sul fur and Equivalent Pyrite in USW G-4 ...................

III. Reference Intensity Ratios (RIR or I/I $)$ for Minerals in Yucca Mountain Tuffs ...........

IV. Tracer Concentration and Water Content in Fracture at a Given Distance fron Source Center......

V. Tracer Concentration and Water Content in Topopah Spring and Calico Hills Experiments........ 


\title{
RESEARCH BY ESS DIVISION FOR THE \\ NEVADA NUCLEAR WASTE STORAGE INVESTIGATIONS
}

\author{
January - June 1985
}

Compiled by

D. Variman

Contributors

$\begin{array}{ll}\text { D. Bish } & \text { S. Chipera } \\ \text { L. Brown } & \text { S. Levy } \\ \text { D. Broxton } & \text { P. Stringer } \\ \text { F. Byers } & \text { B. Travis } \\ \text { B. Carlos } & \text { O. Vaniman }\end{array}$

\section{ABSTRACT}

In January-June 1985, petrographic research for the Nevada Nuclear Waste Storage Investigations focused on xenolithic variability in the Topopah Spring Member and on variations of clinoptilolite composition at Yucca Mountain. Zeolite and smectite occurrences were considered in terms of their relation to a disturbed zone beneath the potential repository, and mineral stability experiments have produced a new clinoptilolite structure as a result of prolonged heating at low temperature. Limitations were defined on the abundance of erionite (a mineral with health-hazard implications) and of sulfur (important to future $\mathrm{pH}$ variability). $X$-ray diffraction studies lead to improved analytical methods. Progress was made in the comparative study of mineralogy in sand ramps and in faults. Geological modeliny considered the differences of the diffusion of nonsorbing tracers in vertically and in horizontally fractured rock. Modeling also treated the diffusion of a nonsorbing tracer in devitrified and in zeolitized rock. The results of these experiments in all cases show relatively symmetrical twodimensional diffusion patterns. Preliminary calculations compare the dispersion/diffusion of nonsorbing Tc with the dispersion/di ffusion/sorption of $U$. 
This report summarizes progress made by the Earth and Space Sciences Division at the Los Alamos National Laboratory (LANL) on research for the Nevada Nuclear Waste Storage Investigations (NNWSI). These investigations are managed by the Waste Management Project Office of the Nevada Office of Operations, U.S. Department of Energy. During the period covered in this report (January through June, 1985), much of the research conducted at Los Alamos was affected by reviews of the Draft Environmental Assessment, Yucca Mountain Site, Nevada Research and Development Area (U.S. Department of Energy, 1984) and by the preparation of the site characterization plan for Yucca Mountain. The writing and review of these documents have helped to provide a critical appraisal of what is being done and why. As one example, the topic of possible spring deposits within faults was raised by external investigators and has become a part of the research program at both the Los Alamos National Laboratory and the U.S. Geological Survey.

The topics covered in this report include mineralogic analysis and experimentation and geochemical modeling. An internal stratigraphy of the potential host rock, the Topopah Spring Member of the Paintbrush tuff, was extended across Yucca Mountain. Clinoptilolite compositions have been found to be different beneath the western and eastern parts of Yucca Mountain. The occurrence of the fibrous zeolite erionite has been confirmed in a fracture in one drill hole at Yucca Mountain. New quantitative x-ray diffraction capabilities are being developed. The mineralogy of fault-related mineral deposits has been found to be very similar to soil-zone mineralogy and not necessarily a result of deep-seated spring activity. A different study, but one that has important implications for near-surface fracture-filling mineralogy, is that of the fractures in horizontal Drill Hole UE-25h\#1 in the eastern flank of Fran Ridge (Fig. 1). Mineral stability investigations have led to the discovery that a new form of clinoptilolite analogous to heulandite-B can be formed from $\mathrm{Na}$-rich clinoptilolite after prolonged heating at $200^{\circ} \mathrm{C}$; this material cannot be formed by short-term hea.ting at any temperature, and it has never been observed before. Modeling of tracer diffusion for exploratory shaft experiments shows that diffusion-limited behavior can be attained within one month after tracer interception of a near-borehole horizontal fracture. A near-borehole vertical fracture causes effects similar to a horizontal one at early periods of such an experiment. A comparison of simulated diffusion 


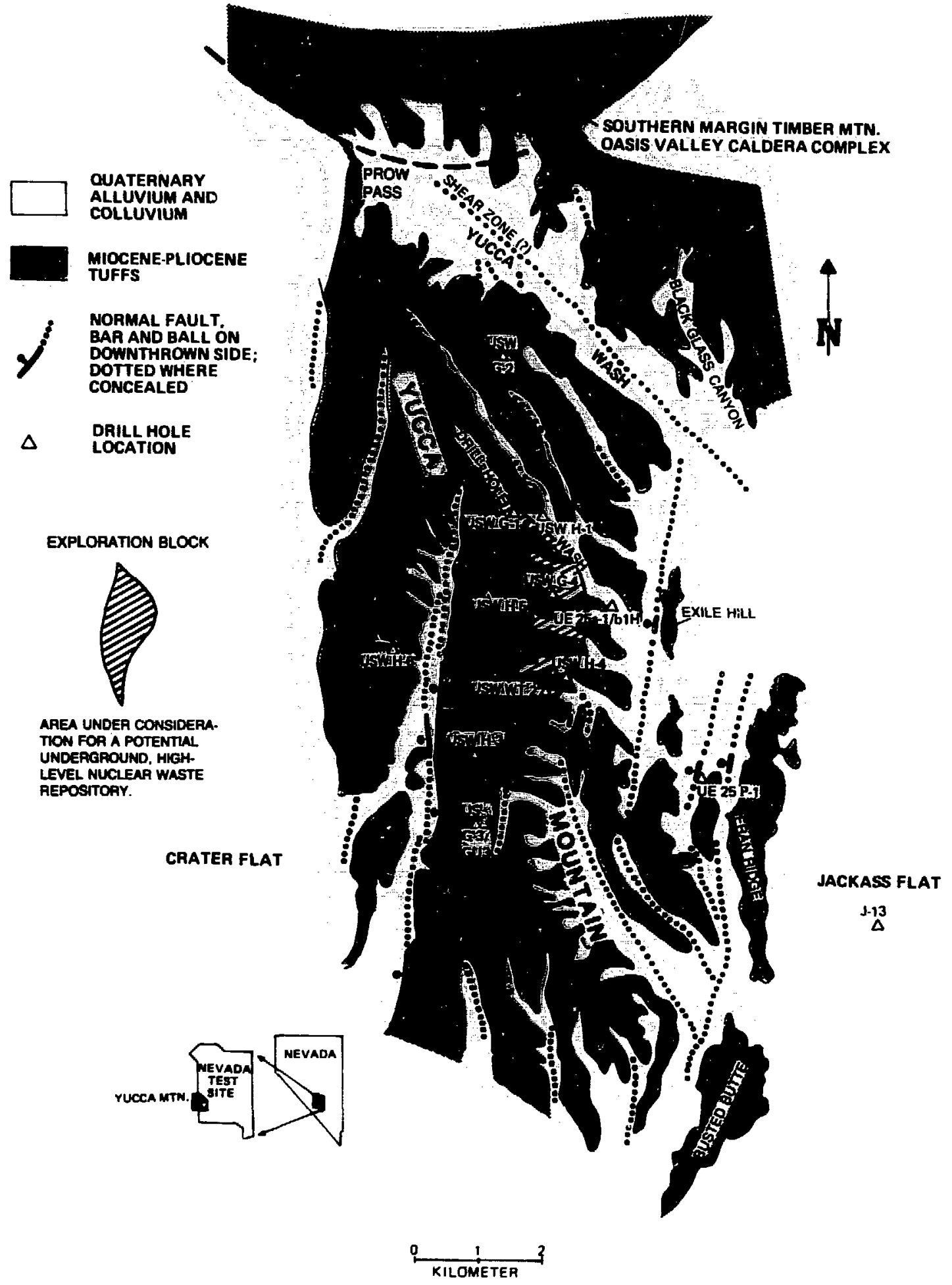

Fig. 1.

Location map of Yucca Mountain. 
experiments on Calico Hills tuff with simulated experiments on Topopah Spring tuff showed that throughout the simulated experiments, Topopah Spring tuff exhibited higher tracer concentrations and faster moving tracer fronts. These topics are discussed in detail below. The appendix sumarizes the preliminary results from a comparison of dispersion/diffusion processes (in retardation of Tc) with dispersion/diffusion/sorption processes (in retardation of $U$ ).

I. MINERALOGY AND PETROLOGY OF TUFF (WBS 2.3.2) (D. Bish, D. Broxton, F. Byers, B. Carlos, S. Chipera, S. Levy, D. Yaniman)

Analysis of the mineralogic and petrologic characteristics of Yucca Mountain tuff samples is one part of a program to characterize the host rock of the potential repository as well as the rocks along potential transport pathways away from the host rock. An important part of the characterization is adequate analysis by $x$-ray diffraction (XRD) because many tuffs are very fine-grained rocks that cannot be adequately analyzed by other methods of determinative mineralogy. Using XRD and petrographic studies in combination is most effective.

The fine-grained and complex mineralogy of tuffs requires that XRD studies be based on powdered samples rather than single crystals. The crystal structures of important fracture-lining manganese minerals have been determined by the Rietveld technique using small amounts of powdered sample. Also, the methods of determining abundances of important minerals within tuff samples are being improved by computer fitting the entire diffraction pattern and by calculating the background correction.

Faults exposed in trenches around Yucca Mountain contain calcite, silica, and sepiolite deposits that some observers have suggested are spring deposits. These deposits are similar in mineralogy to slope-capping and fracture-filling materials which are found in sand ramps near Yucca Montain and which we presently interpret as soil features. Comparisons with other soil and spring deposits are in progress. Studies of the horizontal drill hole at Fran Ridge al so show that a transition from microcrystalline to sparry calcite can simply occur as a function of depth beneath the surface and is not necessarily an indication of spring activity.

Mineral stability experiments have shown that prolonged heating at relatively low temperatures can result in mineralogic changes that are otherwise unexpected. Heating for one year at $200^{\circ} \mathrm{C}$ has produced an altered 
structural form of clinoptilolite, somewhat analogous to the B-transition that occurs in heulandite at about $250^{\circ} \mathrm{C}$. This transition in clinoptilolite has not been seen before and cannot be produced by short-term heating at any temperature. Because this is a new mineral that may be important for long-term repository performance, its sorptive properties are being investigated.

\section{A. Internal Stratigraphy of the Topopan Spring Member}

The petrographic internal stratigraphy of the Topopah Spring Member has been extended from USW G-4 to other cored holes at Yucca Mountain. The petrologic zones described in USW G-4 (Byers, 1985) are very similar to those determined in USW $G-1$ and USW GU-3 (Fig. 1). The petrologic zones of the Topopan Spring in these three holes from top to bottom consist of

1) nonwelded to partially welded vitric tuff

2) upper vitrophyre

3) quartz latite caprock, including vapor phase crystallization

4) upper lithophysal tuff (note: all zones are rhyolitic from here below)

5) middle nonlithophysal tuff

6) lower lithophysal tuff

7) lower nonlithophysal tuff (potential host rock)

8) al tered vitrophyre

9) basal vitrophyre

10) nonwelded to partially welded, variably zeolitic basal tuff.

These zones can be recognized petrographically as well as lithologically and have been defined with the collaboration of $R$. Spengler and $R$. Scott of the USGS. Zones 4 through 7 have al so been recognized in preliminary studies of $x$-ray diffraction data from samples of the Topopah Spring Member. Samples from holes USW G-1 and GU-3 have been requested through the Sample Overview Committee (SOC). These samples will be used to define the contacts of the middle nonlithophysal zone in these holes.

Results of petrographic studies of the Topopah Spring Member in Drill Hole UE-25a\#1 are reported in the LANL October-December 1984 quarterly report (in press). The middle nonlithophysal zone is more spherulitic and more difficult to recognize petrographically in UE-25a\#1 than in USW G-4, G-1, or GU-3; but this apparent difference may not be real as the conclusion is based on a small number of samples.

The principal discovery during the present report period has been the recognition of the xenolith-rich zone of the Topopah Spring Member (Lipman et 
al., 1966) in Drill Hole USW G-2. The xenoliths are mainly fragments of rhyolite with minor fragments of granitic rocks. The matrix is also rhyolitic, similar to the rest of the underlying Topopah Spring. The xenolith-rich zone occurs between the quartz latite caprock and the underlying rhyolitic, upper lithophysal zone; it thickens toward the north, from zero in the exploration block to $68 \mathrm{ft}(21 \mathrm{~m})$ in USW G-2 to about $130 \mathrm{ft}(40 \mathrm{~m})$ north of Yucca Wash (Fig. 1) in Black Glass Canyon (Lipman et al., 1966, p. F13). Lipman et al. remarked that the xenoliths, which constitute about half the rock volume, are packed so closely that they resemble a surficial rubble (Lipman et al., 1966, p. F11). The xenoliths average about $10 \mathrm{~cm}$ in diameter, but some are as large as a meter, as seen in outcrop in Black Glass Canyon north of Yucca Mountain (Fig. 2).

The xenolith-rich zone is recognized in drill core samples from USW G-2 by a high percentage of quartz phenocrysts (Maldonado and Koether, 1983). The groundmass in this zone is microlitic/spherulitic to granophyric, very similar to the enclosing Topopah Spring matrix. The original textures in both xenoliths and the host have been destroyed by the crystallization of the groundmass. The appearance of the xenoliths, medium light gray in color, closely resembles that of the Topopah Spring matrix. Independent examination by the U.S. Geological Survey has confirmed the occurrence of this xenolith-rich zone in USW G-2 from 909.1-ft (277.1-m) to 977.2-ft (297.9-m) depth (R. W. Spengler, USGS, 7/19/85).

The presence of a 68-ft $(20.7-\mathrm{m})$ xenolith-rich zone in hole USW G-2, just below the caprock of the Topopah Spring, indicates that it may also occur elsewhere at Yucca Mountain between Drill Hole Wash and Yucca Wash. The xenoliths in Drill Hole USW G-2 are fewer than in outcrop at Black Glass Canyon, $4 \mathrm{~km}$ to the east, and probably would not constitute an impediment to mining operations. The xenoliths in samples from USW G-2 are "frozen" into the Topopah Spring rhyolitic matrix, unlike those exposed in outcrop at Black Glass Canyon. The xenolith-rich zone thins southward and the xenoliths in it appear to decrease in number and size ( $R$. $W$. Spengler, USGS, 7/19/85). The information gained from candidate hole USW G-5 located between Drill Hole Wash and Yucca Wash should contribute to our knowledge on the southward extent of the xenolith-rich zone.

It has also been found that the nonlithophysal zones in Drill Hole USW G-2 are much thinner than those in drill holes to the south in the exploration 


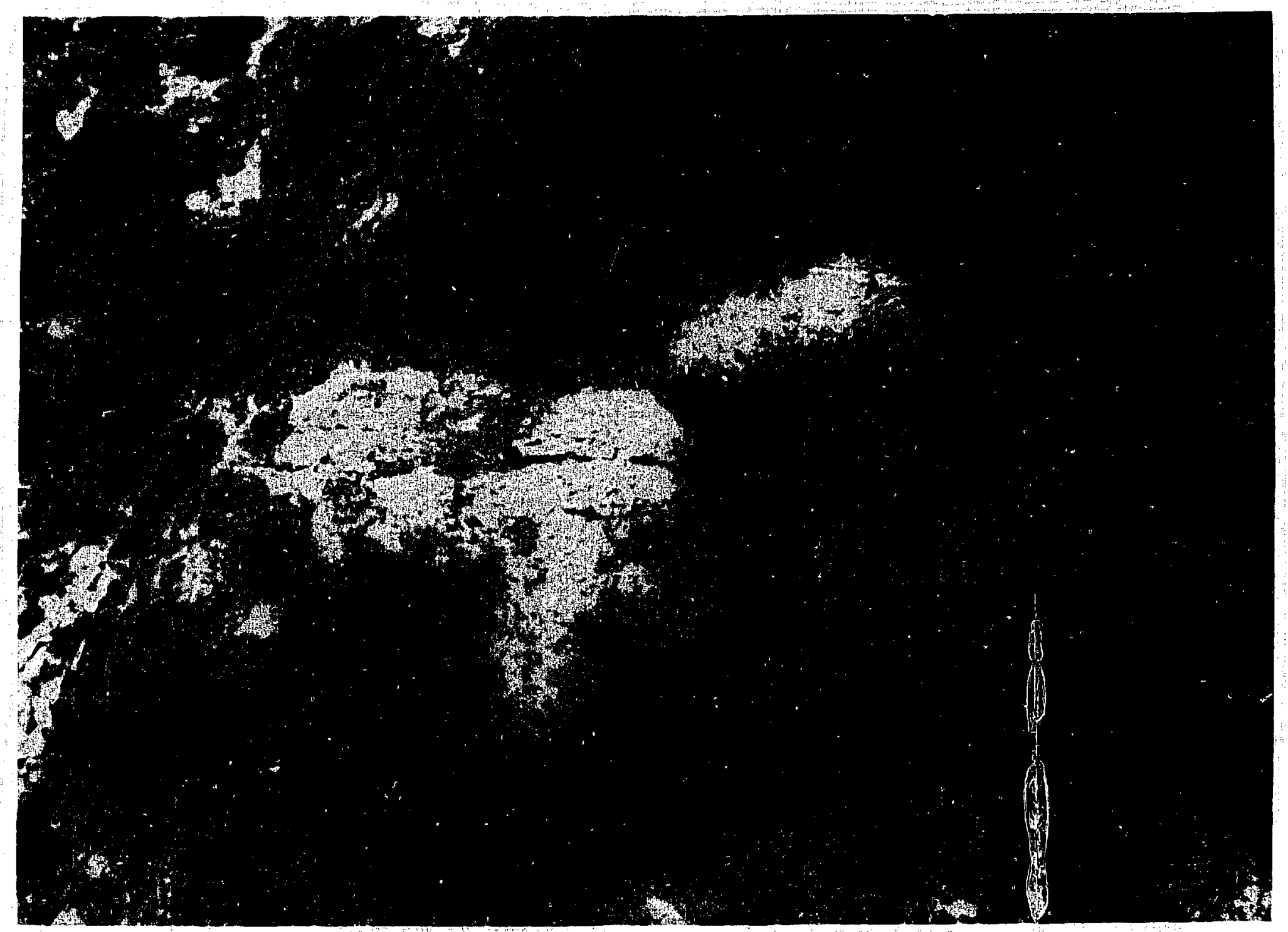

Fig. 2.

$\checkmark$ Outcrop of the Topopah Spring xenolithic zone in Black Glass Canyon. A large (0.5 m) rhyolite xenolith can be seen to the right of the hammer and above the apple. 
block (Fig. 1). The middle nonlithophysal zone, although much thinner in USW G-2 than in USW G-4, can be recognized lithologically on the basis of smaller and much fewer lithophysae (R. W. Spengler, USGS, 7/19/85). This subunit cannot be recognized petrographically in USW G-2, however, because the groundmass has entirely crystallized to spherulitic texture. The lower nonlithophysal zone in USW G-2 can be recognized by the abundance of cryptocrystalline textures.

Comparison of petrographic quantitative criteria for recognizing the petrologic subunits of the Topopah Spring will soon be quantified by statistical treatment. Preliminary results suggest that subunits are quite similar among the three cored holes within the repository exploration blcck but differ slightly from those in UE-25a\#1. Most of the subunits cored in USW G-2, however, differ significantly from those in holes to the south not only in thickness but also in greater degree of crystallinity. B. Comparison of Clinoptilolite Compositions in the Western and Eastern

Zeolites constitute one of the most abundant mineral types at Yucca Mountain. It is important to understand the range of chemical variation within the zeolites as potential sorptive minerals. Variations in zeolite compositions will also affect their dehydration properties and thermal stability (Bish, 1984). Mappable variations in zeolite composition across Yucca Mountain also provide information about the transport and alteration processes that lead to compositional variations.

clinoptilolite is the most abundant and the only ubiquitous zeolite in the interval from the base of the Topopah Spring Member to the base of the crater Flat Tuff at Yucca Mountain. In the zeolitized interval at the top of the Topopah basal vitrophyre (see Section A), the clinoptilolites (ard heulandites; Carlos, 1985) are invariably calcic (Fig. 3). As with other calcium-rich clinoptilolites at Yucca Mountain, appreciable magnesium (a few tenths of a percent to one percent Mg0 by weight) occurs along with the calcium (Table I). Below the Topopah basal vitrophyre, however, there are significant mappable differences between the clinoptilolites that occur in the western and eastern parts of Yucca Mountain.

Figure 4 summarizes the potassium, sodium, and calcium-plus-magnesium variability in clinoptilolites from tuffs below the Topopah Spring basal vitrophyre in the vicinity of the exploration block at Yucca Mountain. Arrows 


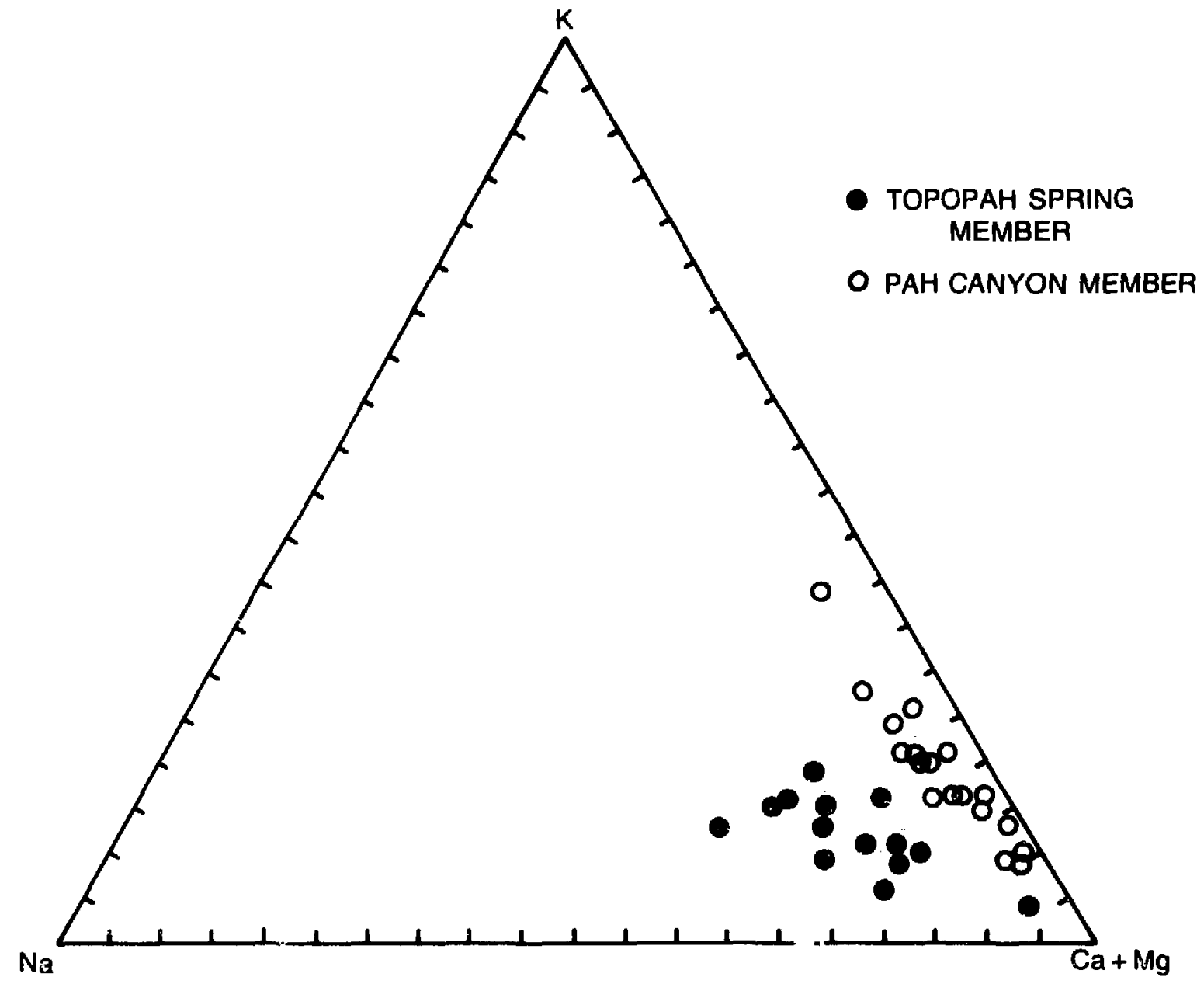

Fig. 3 .

Compositions of clinoptilolites and heulandites at the top of the Topopah Spring Member basal vitrophyre and in the zeolitized Pah Canyon Member. Data for the Topopah Spring Member are from Drill Holes USW G-1, G-2, GU-3, G-4, $\mathrm{H}-4$, and UE-25a\#1; data for the Pah Canyon Member are from Drill Hole USW G-2.

within the ternary diagrams show the trends of compositional variation with increasing depth in each of the drill holes illustrated. Present data indicate that in the western part of the exploration block, clinoptilolites form a potassium-sodium compositional suite in which sodium contents increase with depth (Drill Holes USW G-1, USW H-5, and USW G-3). At the eastern margin of the exploration block and beyond to the east, the calcium- and magnesiumenriched clinoptilolites occur with a tendency toward increasing calcium contents with increasing depth (UE-25a\#1 and b\#1, UE-25p\#1, J-13, and USW H-4). The samples from Drill Hole USW G-4 appear to be transitional, having some properties of both the western alkalic clinoptilolites and the eastern 


\begin{tabular}{|c|c|c|c|c|c|}
\hline \multirow[b]{2}{*}{ Rock Unit } & \multicolumn{3}{|c|}{ Ins aturated Zone } & \multicolumn{2}{|c|}{ Soturated Zone } \\
\hline & $\begin{array}{l}\text { Topopah Spring Mor.., } \\
\text { Psintbrush Tuff, } \\
\text { Top of gasal Vitrophyre }\end{array}$ & $\begin{array}{l}\text { Tuff of Calico Hills, } \\
\text { East Side of } \\
\text { Repository Block } \\
\end{array}$ & $\begin{array}{l}\text { Tuff of Calico H1lls, } \\
\text { Hest Side of } \\
\text { Repos itary Block } \\
\end{array}$ & $\begin{array}{l}\text { Prow Pass Mor } \\
\text { Crater Flat Tuff, } \\
\text { East Side of } \\
\text { Repos itory 8lock }\end{array}$ & $\begin{array}{l}\text { Prow Pass Mor. } \\
\text { Crater Flat Tuff, } \\
\text { West Side of } \\
\text { Repos itory Block } \\
\end{array}$ \\
\hline Sanple Mo.d & $\mathrm{J}-13-1335^{\mathrm{a}}$ & $\underline{\underline{L}} 25 \mathrm{a} 1 \mathrm{1}-1323^{\mathrm{a}}$ & USU 6-1-1774. & 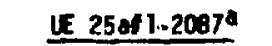 & USW $6-1-2083^{\mathrm{a}}$ \\
\hline $\mathrm{SHO}_{2}$ & 66.0 & 66.1 & 68.1 & 64.1 & 67.3 \\
\hline $\mathrm{THO}_{2}$ & 0.02 & 0.03 & 0.00 & 0.00 & 0.00 \\
\hline $\mathrm{Al}_{2} \mathrm{O}_{3}$ & 13.1 & 11.6 & 12.2 & 12.0 & 11.7 \\
\hline $\mathrm{Fe}_{2} \mathrm{O}_{3}$ & 0,47 & 0.02 & 0.00 & 0.00 & 0.00 \\
\hline $\mathrm{MgO}$ & 0.51 & 0.28 & 0.09 & 0.71 & 0.07 \\
\hline CaO & 4.49 & 4.01 & 1.11 & 3.78 & 0.78 \\
\hline BaO & 0.04 & 0.15 & 0.03 & 0.05 & 0.08 \\
\hline $\mathrm{Na}_{2} \mathrm{O}$ & 1.07 & 0.67 & 2.84 & 0.47 & 3.13 \\
\hline $\mathrm{k}_{2} \mathrm{O}$ & 1.05 & 1.78 & 4.20 & 1.54 & 3.34 \\
\hline TOTAL & 86.7 & 84.7 & 88.5 & 82.7 & 86.4 \\
\hline \multicolumn{6}{|c|}{ Catton Percent } \\
\hline 51 & 72.6 & 74.8 & 71.9 & 74.3 & 72.8 \\
\hline$T i$ & 0.02 & 0.03 & 0.00 & 0.00 & 0.00 \\
\hline A1 & 17.0 & 15.5 & 15.2 & 16.4 & 14.9 \\
\hline $\mathrm{Fe}^{+3}$ & 0.39 & 0.02 & 0.00 & 0.00 & 0.00 \\
\hline $\mathrm{mg}$ & 0.84 & 0.64 & 0.14 & 1.23 & 0.11 \\
\hline Ca & 5.30 & 4.87 & 1.26 & 4.70 & 0.91 \\
\hline Ba & 0.02 & 0.07 & 0.01 & 0.02 & 0.03 \\
\hline $\mathrm{Ma}$ & 2.28 & 1.47 & 5.62 & 1.06 & 6.57 \\
\hline $\mathbf{k}$ & 1.48 & 2.57 & 5.66 & 2.28 & 4.61 \\
\hline \multicolumn{6}{|c|}{ Si/A1 } \\
\hline & 4.3 & 4.8 & 4.7 & 4.5 & 4.9 \\
\hline \multicolumn{6}{|c|}{ Molx Exchangeable Cations } \\
\hline $\mathrm{x}$ & 15 & 27 & 44 & 25 & 38 \\
\hline $\mathrm{Ma}$ & 23 & 15 & 45 & $1 i$ & 54 \\
\hline $\mathrm{Ca}+\mathrm{Mg}$ & 62 & 58 & 11 & 64 & 8 \\
\hline
\end{tabular}


WESTERN
ALKALIC GROUP
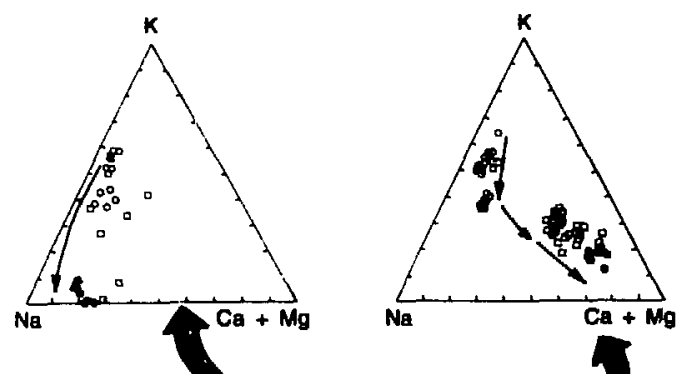

TRANSITIONAL

\section{EASTERN}

CALCIC GROUP

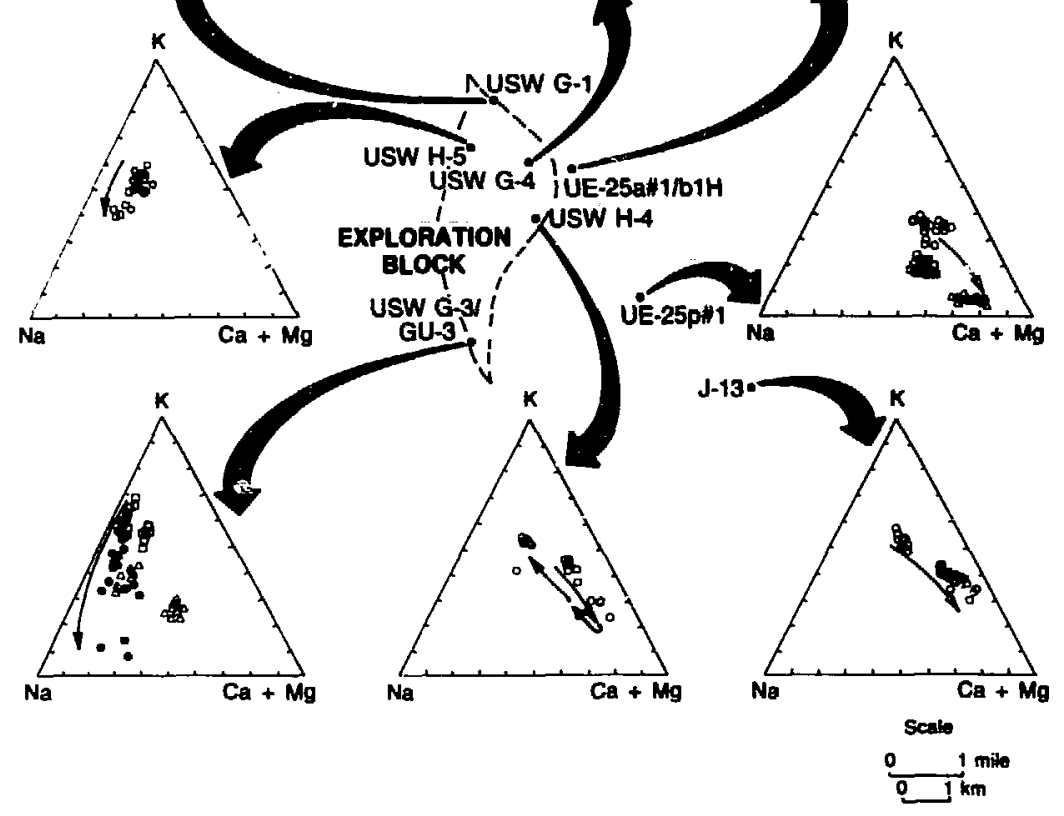

NONWELDED BASE OF TOPOPAH SPRING MBR., TUFF OF CALICO HILLS, AND TOP OF PROW PASS MER.

DONWELDED BASE OF PROW PASS MBR. AND TOP OF BULLFROG MBR.

$\triangle$ NONWELDED TOP OF BULLFROG MBR. AND TRAM MBR.

- PRE-TRAM Volcanic Rocks

NOTE: SMALL ARROWS WITHIN PLOTS INDICATE CHEMICAL TRENDS WITH INCREASING DEPTH.

Fig. 4.

Comparison of the western (alkalic) and eastern (calcic) clinoptilolite series at Yucca Mountain. Arrows and symbols within the ternary diagrams al so show second-order variation with depth (generally decreasing potassium content). 
calcic clinoptilolites. Representative clinoptilolite compositions are listed in Table I.

This difference between western and eastern clinoptilolites is important for understanding the origins of zeolitization at Yucca Mountain. There are several possible explanations for the east-to-west variation in clinoptilolite compositions. One possibility is that the calcium-rich waters from the eastern part of Yucca Mountain (0gard and Kerrisk, 1984) may be responsible for the calcium-rich zeolite compositions found in this region. Another possibility is that paleoflow from east to west beneath Yucca Mountain could lead to an initial zonation of calcium-rich clinoptilolites forming near Jackass Flat (Fig. 1) and alkalic clinoptilolites forming farther away ( $H$. Claassen, USGS, 9/12/85). This second hypothesis would indicate that the exchangeable-cation compositions were set at the time of zeolitization and have not changed. The origins of different zeolite cation series at Yucca Mountain are being investigated by comparing data from drill-hole samples with water compositions and by chemical, isotopic, and radiometric dating studies of zeolites and associated alteration minerals.

C. Mineral Stability and Definition of the Disturbed Zone at Yucca Mountain

In response to a request from Lawrence Livermore National Laboratory (LLNL) (LLNL letter WP: 76-84/558IN), we have made a preliminary attempt to map out the disturbed zone at Yucca Mountain. For the definition of the disturbed zone, we are using "that portion of the geologic setting that is significantly affected by ... the heat generated by the emplacement of radioactive waste" (10CFR60.2). Our studies on the reversibility of zeolite and smectite dehydration will have direct bearing on refinements of the description of the disturbed zone at Yucca Mountain, but for the time being an assessment can be made based on the following data:

(1) Published suggestions that zeolite-bearing horizons may be adversely affected at temperatures above $100^{\circ} \mathrm{C}$ (Smyth, 1982).

(2) Published data from Yucca Mountain that indicate smectites remain expandable even after exposure over long time spans to temperatures up to $100^{\circ} \mathrm{C}$ (Bish and Semarge, 1982).

(3) Ambient temperatures of less than $28^{\circ} \mathrm{C}$ for the base of the Topopah Spring densely welded devitrified host rock (calculated from data in Sass and Lachenbruch, 1982). 
(4) Thickness of critical intervals in drill cores USW G-1, USW GU-3, and G-3, USW G-4, and UE-25a"l (Vaniman et a1., 1984).

(5) The time-temperature-depth curves calculated by D. Montan (LLNL, 1984).

Using data sources (1) through (3) and the thermal history proposed by Montan, it can be estimated that the zone within $20 \mathrm{~m}$ below the repository centerline may be heated to temperatures that might be considered unacceptable for long-term zeolite stability $\left(>100^{\circ} \mathrm{C}\right)$. Combining this result with the major mineralogic zores defined in data source (4) and assuming that the 20-m distance is measured from the lowest possible placement of the repository in the Topopah Spring densely welded devitrified zone would extend this disturbed zone boundary into the upper part of the Calico Hills zeolitized zone (Zeolite Interval II; Bish et al., 1984) northeast of the repository exploration block or into vitric rocks beneath the bloch. This would effectively place the thin zeolitized interval above the Topopah Spring basal vitrophyre (Bish et al., 1984) in the disturbed zone and would not affect the underlying zeolitized intervals except in UE-25a\#1. The placement of the disturbed zone boundary is described below for four representative drill holes.

(1) USW G-1: A11 of the zeolites below the Topopah Spring basal vitrophyre would be outside the disturbed zone; the thin zeolitized interval at the top of the Topopah Spring basal vitrophyre would be within the disturbed zone. Over $140 \mathrm{~m}$ of zeolitized rock remain outside the disturbed zone and above the static water level (SWL).

(2) USW G-4: As in USW G-1, only the thin zeolitized interval at the top of the Topopah Spring basal vitrophyre would be within the disturbed zone. About $125 \mathrm{~m}$ of zeolitized rock remain outside the disturbed zone and above the SWL.

(3) USW GU-3 and G-3: $100^{\circ} \mathrm{C}$ horizon occurs within the Topopah Spring basal vitrophyre; the only abundant zeolites are much farther below, and $57 \mathrm{~m}$ of zeolitized rock occur above the SWL and below the $100^{\circ} \mathrm{C}$ horizon.

(4) UE-25a:1: Similar to USW G-1 and USW G-4, but about $1 \mathrm{~m}$ of those zeolites below the Topopah Spring basal vitrophyre would fall within the disturbed zone; $66 \mathrm{~m}$ of zeolitized rock remain between the disturbed zone and the SWL.

From the standpoint of repository configuration, these are conservative calculations because the repository is assumed to be directly above the 
Topopah Spring basal vitrophyre. All of the zeolites, including the thin zeolitized interval at the top of the Topopah Spring basal vitrophyre, can be put beyond the $100^{\circ} \mathrm{C}$ boundary if the repository were constructed at least $25 \mathrm{~m}$ above the basal vitrophyre at all places.

It is important to emphasize that our concepts of zeolite stability are still very preliminary and will remain so until we have more data on the kinetics of important transitions at low temperatures. Final suggested temperatures for clay and zeolite stability may be higher or lower than $100^{\circ} \mathrm{C}$ (in this regard, this model of the disturbed zone might not be conservative). This is strictly a 'first cut' at a mineralogic definition of the disturbed zone.

D. Occurrence of Erionite at Yucca Mountain

Until recently, the only zeolite minerals that had been positively identified at Yucca Mountain were clinoptilolite, heulandite, mordenite, and analcime. In February 1985, however, a white fracture coating from drill core UE-25a\#1 (1296-ft depth) was analyzed by $x$-ray diffraction and found to be erionite (Fig. 5). This depth is within the vitrophyre at the base of the Topopan Spring Member, below the depth proposed for repository excavations. It is unlikely therefore that this erionite occurrence will be of concern to the NWWSI Project, but it might be anticipated that the implied correlation between erionite and mesothelioma may be raised again as a potential health hazard at the Yucca Mountain site (Mumpton, 1979; Rohl et a1., 1982).

E. Studies of Sulfur Content Within the Topopah Spring Member

Los Alamos has conducted a survey of a number of hot springs in tuffaceous rocks of the western U.S. to determine possible long-range effects of hot water on a tuff repository (Wolfsberg et al., 1983). One of the conclusions of this preliminary work was that highly acid systems had formed at many springs during some stage in their evolution, presumably through the oxidation of sulfide minerals. Evidence for this included highly leached rocks and a variety of sulfate-bearing phases.

We have analyzed a number of thiff samples from Drill Hole USW G-4 for sulfur content to assess the potential for sulfide oxidation and formation of acid conditions in the repository host rock. Analyses were conducted on rock powders with an automated Rigaku x-ray fluorescence spectrometer. The detection limit was $19 \mathrm{ppm}$ sulfur, and the standard deviation of sulfur content was $\pm 12 \mathrm{ppm}$ (Table II). The amount of pyrite, $\mathrm{FeS}_{2}$, required to yield 


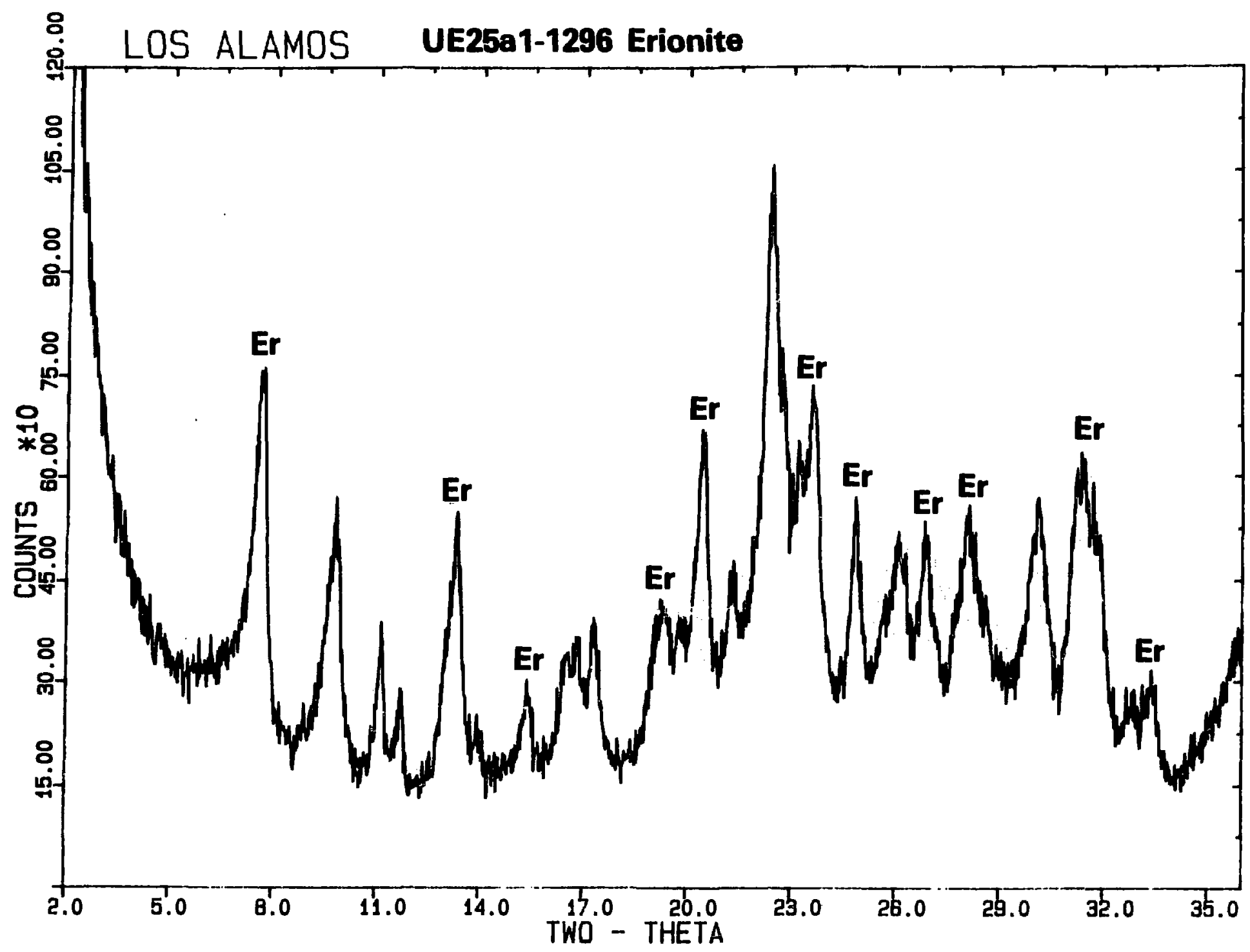

Fig. 5.

$X$-ray diffraction pattern of erionite from a depth of $1296 \mathrm{ft}(395 \mathrm{~m})$ in Drill Hole UE-25a\#1. Erionite $\vec{G}$ peaks are marked (Er); the remaining peaks are clinoptilolite. 
TABLE II. Concentration of Sulfur and Equivalent Pyrite in USW G-4

\begin{tabular}{lccc} 
Sample & $\begin{array}{c}\text { Sulfur } \\
(\mathrm{ppm})\end{array}$ & & $\begin{array}{c}\text { Equivalent Pyrite } \\
(q)\end{array}$ \\
G4-410 & 64 & & 0.0120 \\
G4-817 & 50 & & 0.0094 \\
G4-1089 & 52 & & 0.0097 \\
G4-1117 & 137 & & 0.0256 \\
G4-1244 & 68 & & 0.0127 \\
G4-1301 & 46 & & 0.0086 \\
G4-1330 & 47 & & 0.0088 \\
G4-1369.6 & 68 & & 0.0127 \\
G4-1392 & 51 & & 0.0095 \\
G4-1419 & 72 & 0.0135 \\
\hline
\end{tabular}

a Minimum detection limit $=19 \mathrm{ppm} ;$ all analyses are \pm $12 \mathrm{ppm}$.

an equivalent amount of sulfur is also shown in Table II. Assuming that all sulfur in these rocks is present as pyrite, all of the pyrite is oxidized, and the amount of water present is $5.5 \%$ by weight (Montazer and Wilson, 1984), oxidation of pyrite will produce between $4.7 \times 10^{-4}$ and $1.4 \times 10^{-3}$ moles of sulfur per mole of $\mathrm{H}_{2} \mathrm{O}$ or between $9.4 \times 10^{-4}$ and $2.8 \times 10^{-3}$ moles of $\mathrm{H}^{+}$per mole of $\mathrm{H}_{2} \mathrm{O}$. This is equivalent to a range of 0.026 mole to $0.078 \mathrm{~mole}_{2} \mathrm{SO}_{4}$. Ogard and Kerrisk (1984) have specifically dealt with the pH buffering capacity of Yucca Mountain waters. Their study indicates that the buffering capacity of the minerals at Yucca Mountain in contact with water of well J-13 type can compensate for this increased $H+$ addition without any significant increase in acidity. Their model allows for the addition of at least three times as much oxidized pyrite with no significant increase in $\mathrm{pH}$. 
1. Rietveld Refinements of Manganese 0xide Minerals. Manganese oxide minerals occur in fractures throughout the potential host rock at Yucca Mountain, the welded devitrified portion of the Topopah Spring Memsei. They also occur in fractures within the surrounding rock units. Although minor constituents of the bulk rock (much less than nnt jercent), their concentration along fracture surfaces gives them i potentially much greater significance in retardation by sorption. To date, the manganese oxide minerals todorokite (Caporuscio et al., 1982), cryptomelane (Vaniman et al., 1984), and pyrolusite (Scott and Castellanos, 1984) have been identified within fractures at icca Mountain; lithiophorite may also occur (Vaniman et al., 1984). A significant problem in characterizing these minerals, however, is the fact that they occur in finely crystalline masses that yield poor $x$-ray powder diffraction (XRD) patterns.

In order to adequately characterize these important minerals, we have worked with J. E. Post of the Smithsonian Institution, using the Rietveld refinement technique for powder XRD data. As a first test of this methor, some otherwise well-characterized and commonly available samples of todorokite, romanechite, and coronadite (same structure as cryptomelane) were used.

The romanechite structure had been previously solved from two-diniensional single crystal $x$-ray data, but the todorokite and coronadite structures had not been refined. Controversy exists over the structure of todorokite, a manganese mineral which occurs at Yucca Mountain; both layer and tunnel structures have been proposed. Before discussing our results on todorokite, it is worth comparing the results of the Rietveld method with the more traditional results in a study of romanechite and coronadite.

Our Rietveld refined structure of romanechite agrees well with that determined previously but provides additional details. Electron density maps show that barium is not at $y=0.0$ as previously suggested (Wadsley, 1953), but it is displaced off of the mirror plane and exhibits anisotropic motion along the tunnel axis. The refined structure of coronadite is close to those determined by single crystal methods for other hollandite minerals (such as cryptomelane, which occurs at Yucca Mountain) (Post et al., 1982). In coronadite, lead is displaced off of the special symmetry position in a manner similar to the barium displacemant in other hollandite compounds. 
Our refinement of todorokite provides the first confirmation of the $3 \times 3$ tunnel structure proposed by some previous studies (Turner and Buseck, 1979) and provides information on the positions of the tunnel cations. Our technique was capable of structurally locating such important constituents as $\mathrm{Na}$, $\mathrm{Ca}$, and $\mathrm{H}_{2} \mathrm{O}$. The oxygen positions were determined with relatively poor precision, but our data show that valuable structural information can be obtained for minerals yielding XRD patterns with broad, overlapping peaks.

Future work will apply the Rietveld refinement technique to samples from Yucca Mountain. Although the framework oxygen positions may not be well defined as a result of these studies, the nature and position of large cations is important for considering sorption properties. Also, the nature and location of large cations have important implications for past movement or retardation of heavy trace elements through fractures at Yucca Mountain.

2. Improved Quantitative XRD Capabilities. We have recently modified our method of quantitatively analyzing rock samples using $x$-ray powder diffraction for mineral components (Bish and Vaniman, 1985). In the past we used the external standard method (the matrix-flushing method) because it is rapid and relatively easy to perform. To improve the precision and accuracy of our analyses, we have recently implemented the internal standard technique, using Linde $A$ or $C$ corundum as an internal standard (Chung, 1974a,b). With this technique, a known amount of internal standard corundum is added to each sample. Reference peaks of minerals in the sample are then related to the internal standard peaks.

Corundum was chosen as our internal standard for a variety of reasons. It is readily obtainable in large volumes of high purity, is inexpensive, and is not a mineral phase found in the rocks we are studying. In addition, its most intense peak $\left(43.3^{\circ} 2 \theta\right)$ is not overlain by the diffraction peaks of most other minerals, and its own peaks do not overlap other mineral reference peaks.

As with the external standard method, the internal standard method requires that reference intensity ratios (RIR, or I over I corundum) be known for every phase in the rochs to be analyzed. RIRs are determined from the ratio of the integrated intensity of the mineral's reference peak to the integrated intensity of the $43.3^{\circ} 2 \theta$ corundum peak. We have obtained additional standards for the minerals in Yucca Mountain tuffs and have measured RIRs for every mineral mixed in a 50:50 ratio with Linde $A$ corundum. Calcite, biotite, albite, and sanidine were mixed in a 20:80 ratio to help reduce 
problems with preferred orientation. Table III shows the average RIRs from six independent runs for several reflections. RIRs calculated from single crystal data are shown for those minerals that showed significant preferred orientation in the standard runs or were not obtainable in high enough purity for a mineral standard. These RIRs are used in both our internal and external standard analyses.

Using the Rietveld quantitative analysis technique, we have recently discovered that Linde $A$ corundum contains a small amount $(\sim 2 \%)$ of gamma $\mathrm{Al}_{2} \mathrm{O}_{3}$. We therefore are currently using Linde $C$ corundum with our standards.

This summer, S. Howard from the University of Missouri at Rolla visited LANL for a period of several weeks to work on an improved method of quantitative XRD analysis. Quantitative analysis by XRD is particularly important in tuff studies, where the very fine grain size of most samples makes this the only method that gives reliable quantitative mineralogic data. The newly developed method is now possible only because of the recent connection between the Siemens XRD system and a VAX computer. The method employs fitting of the entire pattern and a calculated background correction, and it will enable quantitative information to be obtained as well as structural information on individual components of the mineral mixtures that comprise tuff. Data that are put into our code include approximate crystal structural parameters, including atom positions and unit-cell parameters, for every crystalline phase in the rock. Quantitative analysis is accomplished by determining, via least-squares refinement, the best fit between the cbserved XRD pattern and the calculated theoretical pattern. Major variables in this process are the amounts of the minerals present, and secondary variables are the unit-cell parameters and atom positions for the individual phases. Also included in the least-squares refinement are parameters describing the background and the shape of the XRD profiles. Errors are calculated throughout this process, and final weight percents include calculated standard deviations. The resulting output includes best estimates of the above parameters and a plot illustrating observed and calculated patterns, the difference between the two, and calculated positions of diffraction maxima. This not only gives us a visual idea of how reliable our results are, but it also indicates whether all phases have been accounted for. The code is now in the testing phase; an example of its application to a two-phase standard mixture is shown in Fig. 6. This automated technique is a major breakthrough in quantitative mineralogical analysis 
TABLE III. Reference Intensity Ratios (RIR or I/I ${ }_{C}$ ) for Minerals in Yucca Mountain Tuffs

\begin{tabular}{|c|c|c|c|c|c|c|}
\hline Mineral & Peak $\left.{ }^{(2 \theta} \mathrm{Cu}^{\prime}\right)$ & $I / I_{C}$ & Peak $\left({ }^{2 \theta}{ }_{\mathrm{Cu}}\right)$ & ${ }^{I / I} \mathrm{C}$ & Peak $\left(2{ }^{2} \mathrm{Cu}\right)$ & $\mathrm{I}_{\mathrm{C}} \mathrm{C}$ \\
\hline Smectite & 6.0 & 3.2 & & & & \\
\hline Clinoptilolite & 9.8 & 1.2 & $22.4+22.7$ & 0.81 & 29.9 & 0.53 \\
\hline Mordenite & 9.8 & 0.56 & 19.6 & 0.20 & 25.7 & 0.65 \\
\hline Quartz & 26.66 & 4.19 & 20.85 & 0.86 & & \\
\hline Cristobalite & 21.99 & 4.91 & 36.1 & 0.84 & & \\
\hline Tridymi te & 20.5 & $1.6^{\mathrm{a}}$ & 21.64 & $1.80^{\mathrm{a}}$ & & \\
\hline Albite & 13.8 & 0.23 & & & & \\
\hline Sanidine & 23.6 & 0.55 & & & & \\
\hline Calcite & 29.4 & 2.96 & 48.5 & 0.58 & & \\
\hline Analcime & 15.8 & 1.3 & 26.0 & 1.8 & & \\
\hline Biotite & 8.8 & $2.0^{\mathrm{a}}$ & & & & \\
\hline Hematite & 33.2 & 1.7 & 35.7 & 1.2 & & \\
\hline
\end{tabular}

and will be routinely used when a MicrovaxIJ is integrated with the Siemens system within the next year.

G. Studies of Fault-Related Minerals and of Spring Deposits Around Yucca Mountain

Controversy continues over the interpretation of mineral deposits within faults around Yucca Mountain. It is important to resolve the question of whether or not some of these mineral deposits are the result of past spring activity because spring flow could provide a more rapid access of waste to the surface than would downward flow to the water table. During this reporting period, progress was made in defining a joint USGS-LANL approach to resolving this issue.

Joint meetings between LANL and USGS personnel determined that a multidisciplinary program of field work, mineralogy, petrology, geochemistry, 


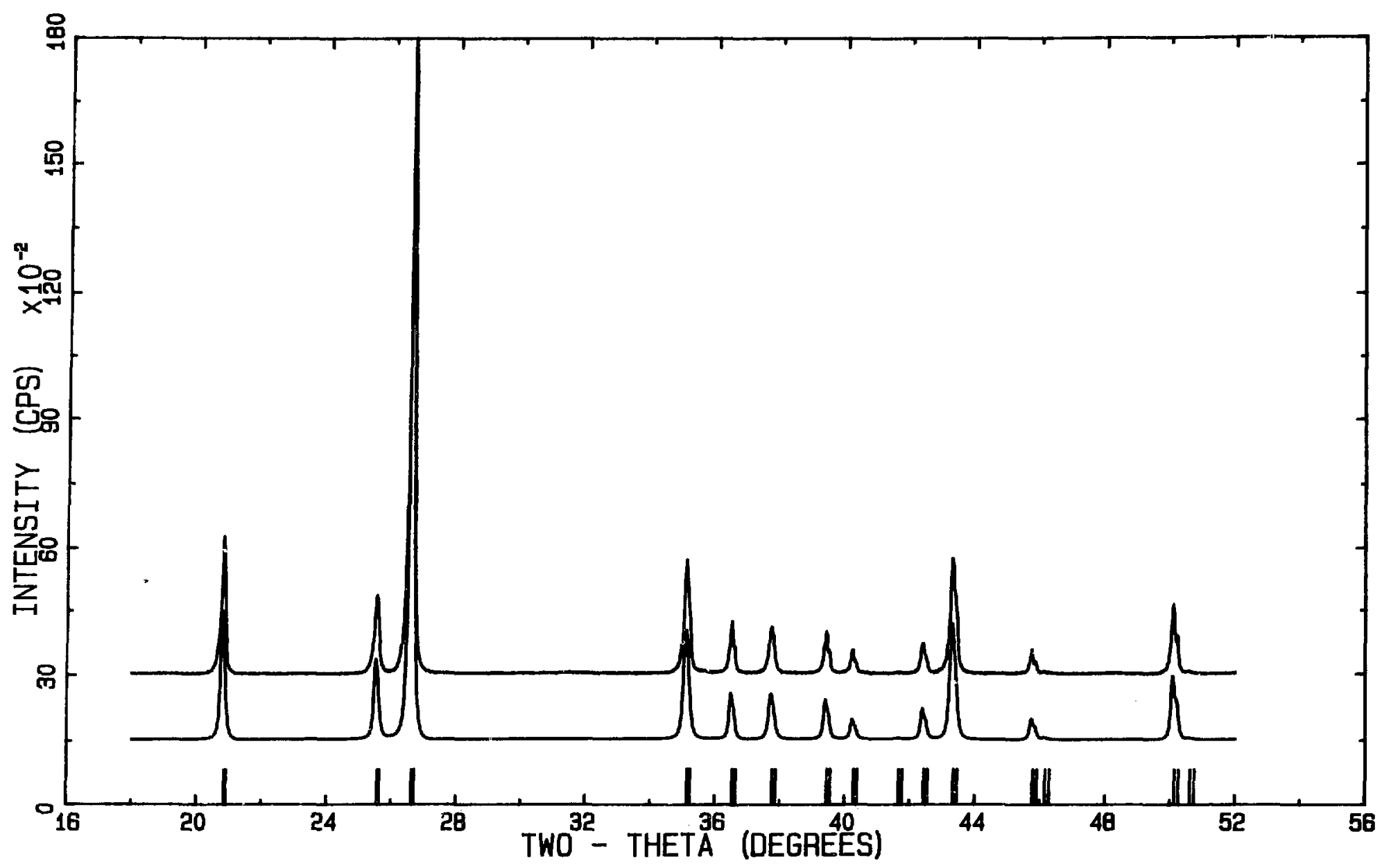

Fig. 6.

Observed x-ray diffraction pattern (upper) and calculated pattern (1ower) for a 50:50 weight mixture of quartz and corundum. The lowermost marks show the calculated positions of all $k_{1}$ and $k_{2}$ reflections for this mixture. 
paleontology, active and modeled hydrology, stable isotope studies, and radiometric dating is necessary. No single line of evidence will be definitive in proving or disproving a spring origin. Because this is a nontraditional problem in geologic studies, a multidisciplinary approach will provide the breadth of data needed to constrain the origins of the deposits around Yucca Mountain.

The major goal of the LANL portion of the multidisciplinary approach to this research problem is the development of a determinative method based on mineralogy for distinguishing spring from non-spring deposits. Field work during this period concentrated on a suite of sample types from trenched faults at Yucca Mountain, as well as samples from the currently flowing spiing system of Cane Spring and from the deposit above Wahmonie that has been previously interpreted as a hot-spring deposit (U.S. Department of Energy, 1984, pp. 2-14). Cane Spring is a cool discharge from a perched aquifer. There are thin coatings of very fine-grained calcite along fractures from which the spring flows. The sepiolite, opal, amorphous silica assemblage that occurs in the faults at Yucca Mountain does not occur at Cane Spring. The reported spring deposit above Hahmonie (U.S. Department of Energy, 1984) consists almost entirely of gypsum, with a coarse cellular structure of slightly calcite-enriched septae surrounding gypsum zones about 10 to $20 \mathrm{~cm}$ across. $x$-ray diffraction shows no other minerals at this locality except gypsum and calcite. Both of these localities, comprising a known and a suspect spring, have mineralogies significantly different from the fault-related deposits around Yucca Mountain.

Comparison of the features deposited from solution along the slopes and fractures in sand ramps around Yucca Mountain with the calcite - silica sepiolite mineralogy that occurs near the surface within fault zones reveals no significa! $;$ differences in mineralogy. Figure 7 compares the XRD patterns of silica-bearing deposits from the sand ramp at Fran Ridge with fault-related calcite - silica - sepiolite deposits within the fault exposed in Trench 17. Both patterns are very similar, showing assemblages dominated by calcite and opal-CT (opal with cristobalite- and tridymite-type structure) with lesser quartz and sepiolite. After treatment with dilute $\mathrm{HCl}$ and separation of the <2-um-size fraction, both types of localities can be shown to contain very similar opal-CT and sepiolite patterns. Seams of amorphous silica have also been found in Trench 14, but this material is closely related to the opaline 

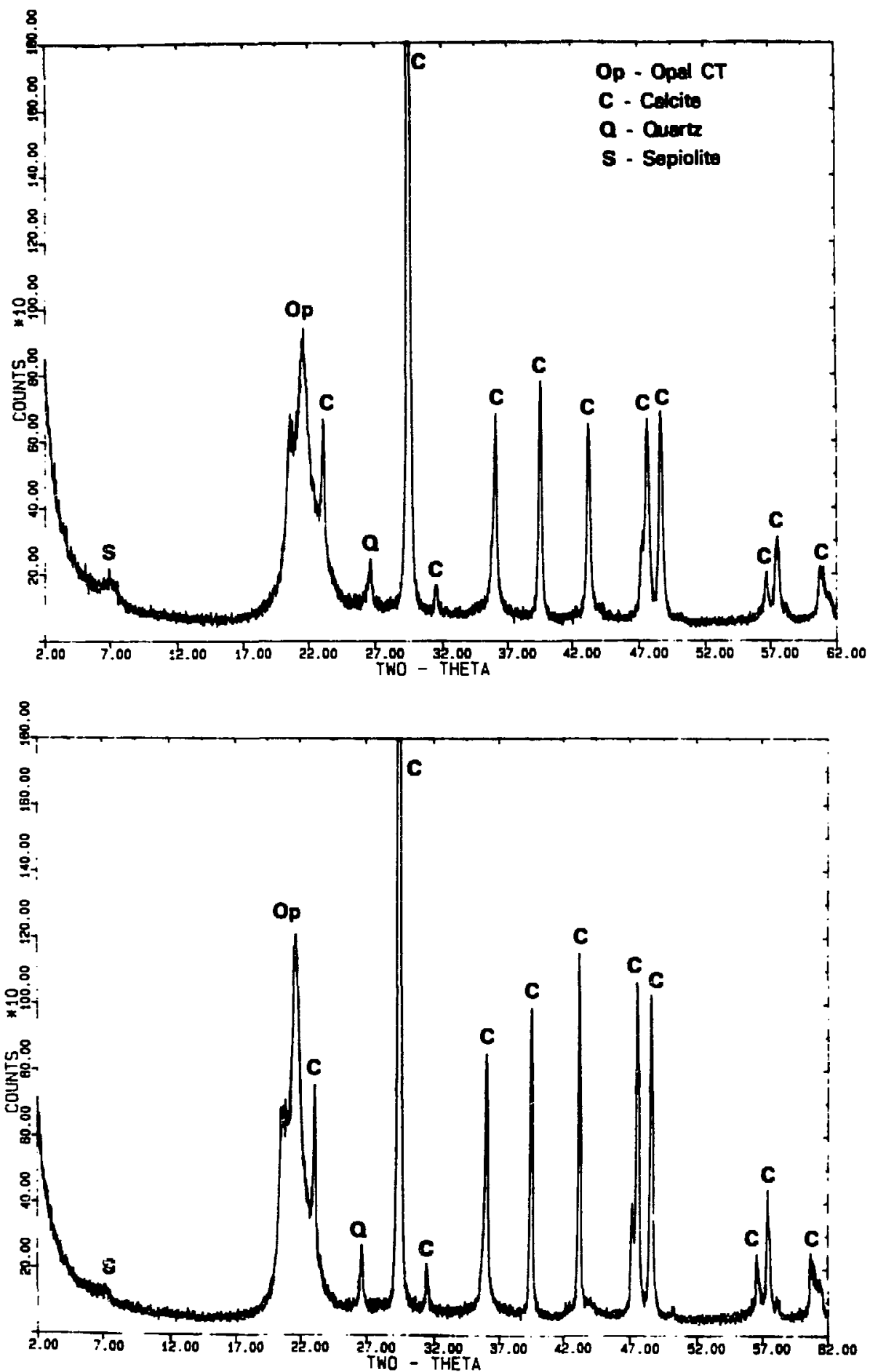

Fig. 7.

XRD comparison of features deposited from solution along the sand-ramp slope at Fran Ridge (upper pattern, FR6) and along the fault exposed in Trench 17 (lower pattern, TR17). 
deposits and its occurrence may be controlled by near-surface flowage in open fractures.

Our present interpretation of the sand ramp deposits is that they are formed through soil-zone solution and deposition. Based on the directly comparable mineralogy of sand-ramp and fault-related samples, we presently see no reason to assume an origin.for the fault-related minerals that would be significantly different from the soil-zone origin of similar sand-ramp minerals. If a soil-zone origin can be proven for these minerals in the sand ramps, then there is no mineralogic evidence requiring a deep-seated spring origin for the calcite - silica - sepiolite deposits that occur within faults at Yucca Mountain.

H. Interim Report on Fracture Mineralogy in the Horizontal Drill Hole at Fran Ridge

A LANL report titled "Fran Ridge Horizontal Coring Summary Report: Hole UE-25h\#1, Yucca Mountain, Nye County, Nevada" (Norris et al., in prep.) has been prepared. This report is a discussion of the capabilities and problems of horizontal drilling in welded devitrified tuff. However, study of the samples returned from this project has yielded useful information on fracturerelated near-surface alteration at Yucca Mountain. Fractures were either smooth and nonmineralized, calcite coated, silica coated, or manganese oxide coated. Open fractures with caliche (porous, nonsparry calcite) were not observed beyond $83.5 \mathrm{ft}(25.4 \mathrm{~m})$ along the drill direction, correspording to a depth of overburden of $30 \mathrm{ft}(9.1 \mathrm{~m})$. Sparry calcite was found just beyond this depth, providing a data point for the maximum depth of caliche formation and a depth of possible caliche to coarse-grained calcite recrystallization. This near-surface mineralogic transition has important implications for comparable fault-related carbonate mineralogy where a possible spring origin has been suggested for the deposit (see Section $G$ above). The Fran Ridge drill-core fracture mineralogy will provide an important baseline (data point) for defining exactly which mineralogic features are unique to the fault-related mineral assemblages that occur elsewhere at Yucca Mountain. The transition from microcrystalline to sparry calcite that occurs in the horizontal drill core suggests that fracture circulation and transport may play an important role in calcite deposition, and processes such as deep-origin spring flowage need not be invoked as an origin for calcite spar. 
1. Formation of a New Zeolite Mineral in Long-Term Heating Experiments.

Clinoptilolite standards from Buckhorn, New Mexico; Fish Creek Mcuntains, Nevada; and Castle Creek, Idaho, have been heated for one year at $100^{\circ} \mathrm{C}$ and $200^{\circ} \mathrm{C}$ to evaluate the possible effects of long-term, relatively low-temperature heating on zeolite structure and sorptive properties. Sorption exprriments are in progress on these samples, and preliminary studies of the end products by XRD show that the long-term heating at $200^{\circ} \mathrm{C}$ has produced a modification of clinoptilolite that cannot be formed by short-term heating at the same or much higher temperatures (Fig. 8). The Na-rich Castle Creek, Idaho, sample that was heated at this temperature for one year was converted to a previously unknown mineral structure, perhaps a clinoptiiolite equivalent of the heulandite- $B$ structure. This experiment demonstrates the importance of kinetic effects on zeolite stability in a repository environment.

II. GEOLOGICAL MODELING (WBS 2.3.1.7) (P. Stringer and L. Brown)

A. Recent Progress in Tracer-Diffusion Experiments for Fractured Rock

Two numerical experiments have been completed that model tracer diffusion within Calico Hills (zeolitized) rock containing a fracture. In one experiment the fracture was assumed to be horizontal; in the other the fracture was assumed to be vertical. In addition, another numerical experiment comparing diffusion in the Tuff of Calico Hills with diffusion in the Topopah Spring Member has been completed.

1. Modeling of Numerical Horizontal Fracture Experiment. Simulations of tracer diffusion from a horizontal fracture have been run studying the diffusion of a nonsorbing tracer with a pure water diffusion coefficient of $1.0 \times 10^{-7} \mathrm{~cm}^{2} / \mathrm{s}$. The diffusion coefficient was taken to be independent of water content, and a linear model results. The hydraulic properties for the Calico Hills material were based on the following model:

$$
P_{c}=\frac{1}{a}\left[\left(\frac{s-s_{w i}}{I-s_{w i}}\right)^{-1 / \lambda}-1\right]^{1 / \beta}
$$




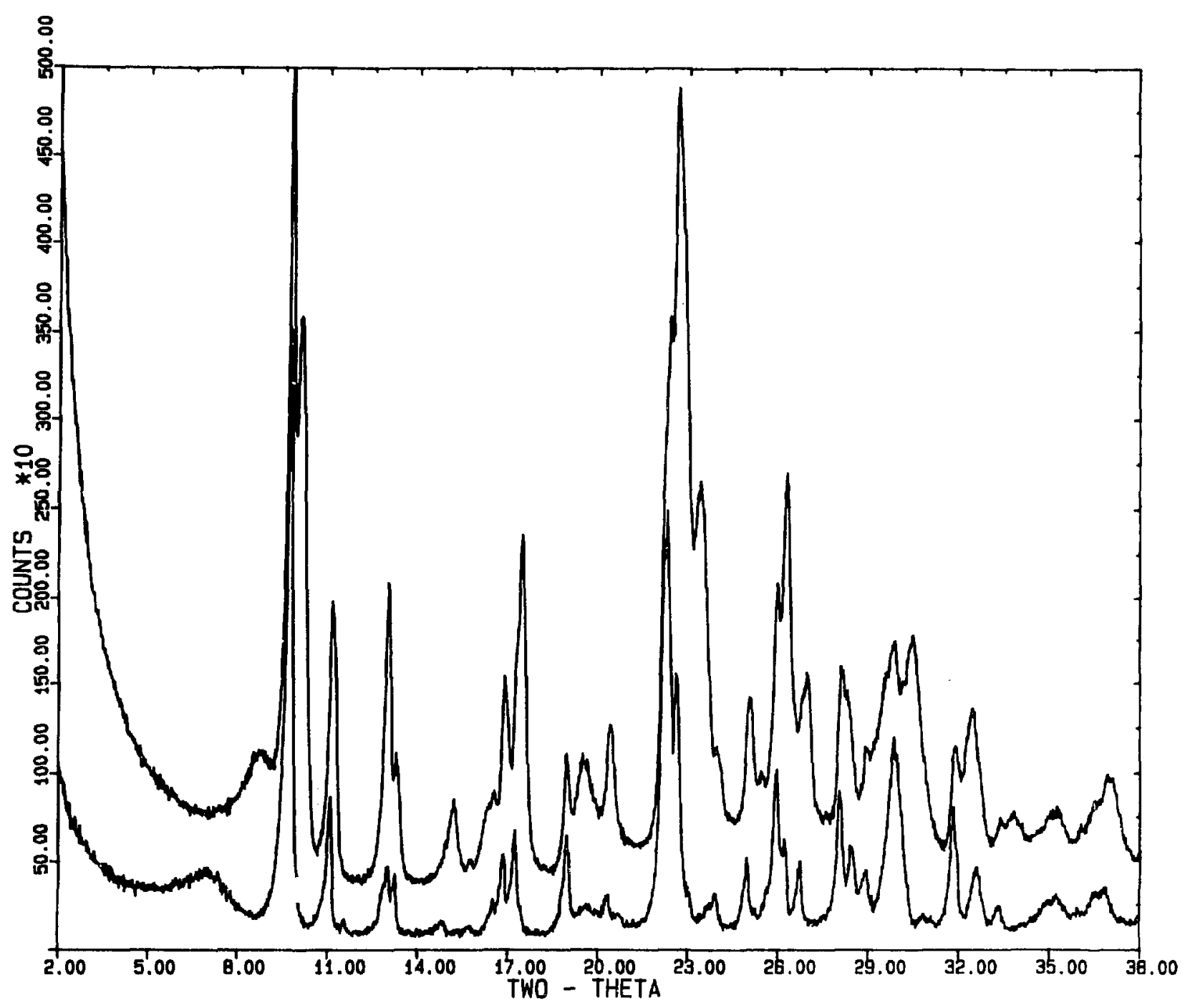

Fig. 8.

Original sample of sodium-exchanged (Na-rich) Castle Creek clinoptilolite (lower pattern), with structure resulting from $200^{\circ} \mathrm{C}$ heating for one year superposed. 


$$
\begin{aligned}
& K_{r}=\left[1+\left(a P_{c}\right)^{\beta}\right]^{-\lambda / 2}\left[1-\left(\frac{\left(a P_{c}\right)^{\beta}}{1+\left(a P_{c}\right)^{\beta}}\right)\right]^{\lambda / 2} \\
& K=K_{r} K_{s}
\end{aligned}
$$

where: $K$ = permeability

$$
\begin{aligned}
& K_{r}=\text { relative permeability } \\
& K_{S}=\text { saturated permeability } \\
& P_{c}=\text { capillary pressure } \\
& s=\text { water content } \\
& S_{W i}=\text { residual water content } \\
& \lambda=1-1 / \beta .
\end{aligned}
$$

The constants $s_{w i}, K_{s_{j}} \beta$, and a were taken as $0.0809,2.068 \times 10^{-6}$ darcys, 1.489 , and $3.65 \times 10^{-5}$ for the matrix respectively. For the fracture all the constants were the same except for $k_{s}$, which was 12.8 darcys.

The simulations assumed a vertical borehole $3 \mathrm{~cm}$ in diameter with a packed-off tracer source section at the end of the borehole. The borehole walls and the top of the tracer-addition section were numerically restricted so that water could not flow across them. Grid spacings of $0.5 \mathrm{~cm}$ were set up in the $x$ and $z$ directions, and radial symmetry was assumed. The horizontal fracture $(0.01 \mathrm{~cm}$ wide) was surrounded by $z$-direction grid spacings of 0.05 and $0.1 \mathrm{~cm}$. The matrix and fracture saturations were initially taken as 0.7 with porosities of 0.33 , and the hydraulic properties for the tracer source were assumed to be the same as those of the matrix. The tracer-source water content was initially set at the saturated level. At time $t=0$, a tracer concentration of $1 \mathrm{~g} / \mathrm{cm}^{3}$ was placed in the source region and allowed to diffuse into the matrix.

The water-content profile came to equilibrium quickly; about 10 days were required for this in the presence of the horizontal fracture as compared with about 18 days for the unfractured rock. The tracer-source water ran quickly out through the fracture rather than diffusing with radial uniformity as it did when no fracture was present. This caused an early variation in tracer-concentration profiles, which lasted up to one month. After about one month, the tracer was moving by pure diffusion without bulk flow in both the 
fractured and unfractured rocks. The modeling equation was the same for both cases:

$$
a(\varepsilon \sigma \rho C)=\nabla\left(\varepsilon \sigma \tau_{C} D \rho \nabla C\right)
$$

where: $\varepsilon=$ porosity

$\sigma=$ water content

$\rho=$ density

$\tau_{c}=$ constrictivity

$D$ = diffusion coefficient

$\mathrm{C}=$ tracer concentration.

This equation neglects bulk flow and sorption effects. Because the porosity, density, constrictivity, and diffusion coefficient are the same, and the water contents and tracer concentrations are similar, tracer movement will be similar for both cases.

Two typical sets of tracer-concentration profiles for the fractured rock experiment are shown in Figs. 9 and 10 . One is for 5.1 days into the experiment, the other for 1.8 months. These figures show a vertical slice through the center of the rock with the left axis corresponding to the center of the borehole. After 5.1 days, the distortions of the profiles caused by the fracture are readily apparent. These distortions gradually decreased and after about a month were no longer visible. There is no apparent distortion in the profiles of the 1.8-month figure (Fig. 10), and indeed there is no discernible difference between the profiles in the fractured rock (Fig. 10) and those obtained for the unfractured rock (Fig. 11) at the 1.8-month point.

\section{Summary of Horizontal Fracture Experiment}

In the first of these numerical experiments, a 0.01-cm-horizontal fracture was placed $1.15 \mathrm{~cm}$ below the source of the tracer, and the resulting tracer profiles and liquid velocity plots ware compared with those from an unfractured mode1. The tracer was not specified but was assumed to have a diffusion coefficient in water of $1.0 \times 10^{-7} \mathrm{~cm}^{2} / \mathrm{s}$. The initial source-water content of the rock was set to saturation, the rock porosity was set at 0.99 , and the tracer concentration at $1.0 \mathrm{~g} / \mathrm{cm}^{3}$. The tracer was allowed to diffuse unimpeded through a matrix and fracture with uniform initial water content of $0.7\left(\mathrm{~cm}^{3}\right.$ water $/ \mathrm{cm}^{3}$ voids $)$ and a porosity of 0.33 for a period of six months. It 


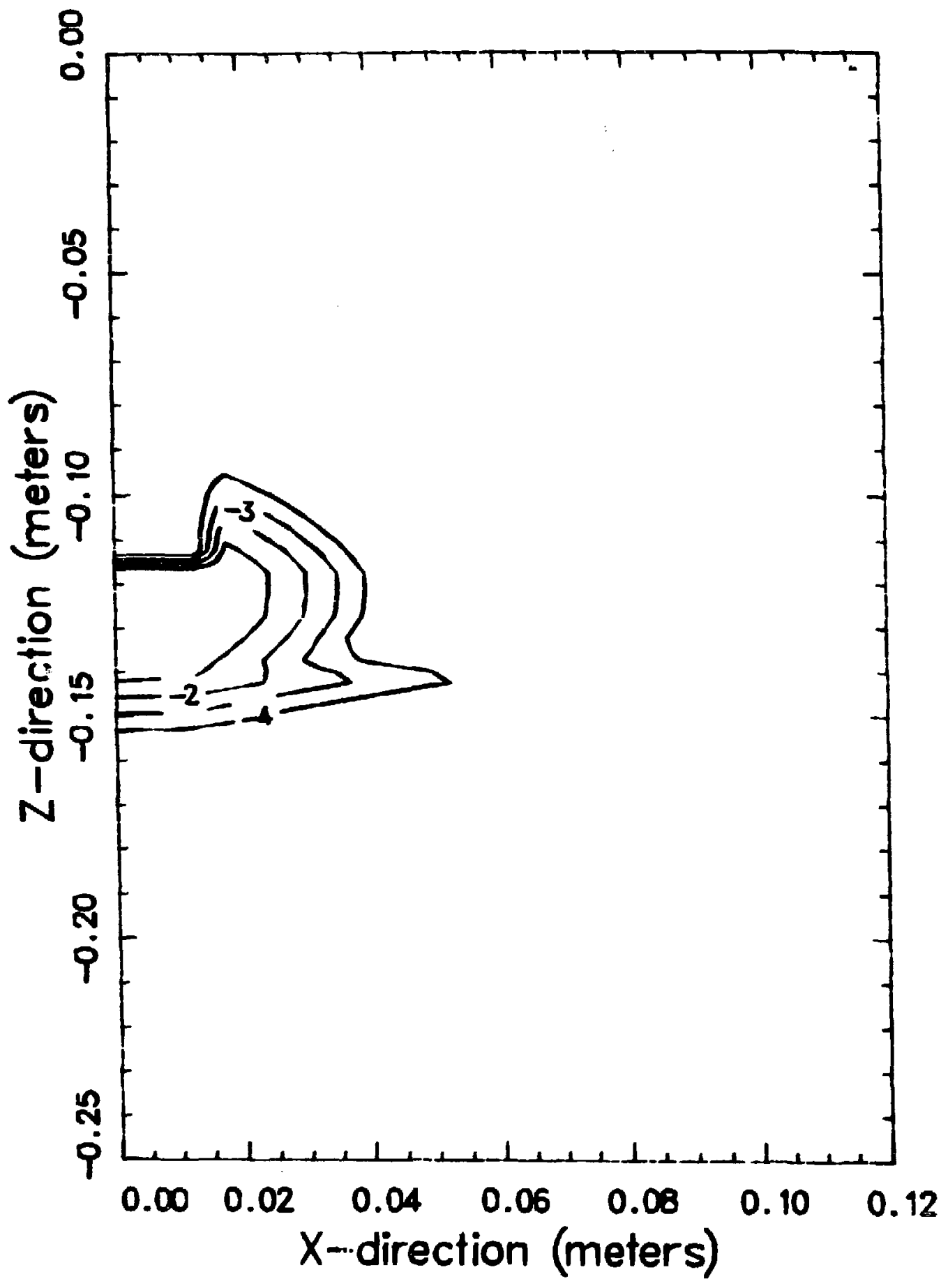

Fig. 9.

Continuous outflow boundary tracer-concentration profiles at 5.1 days calculated for horizontally fractured tuff of Calico Hills (zeolitized). Contours indicate the $\log$ of tracer concentration in $\mathrm{gm} /\left(\mathrm{cm}^{3}\right)$. 


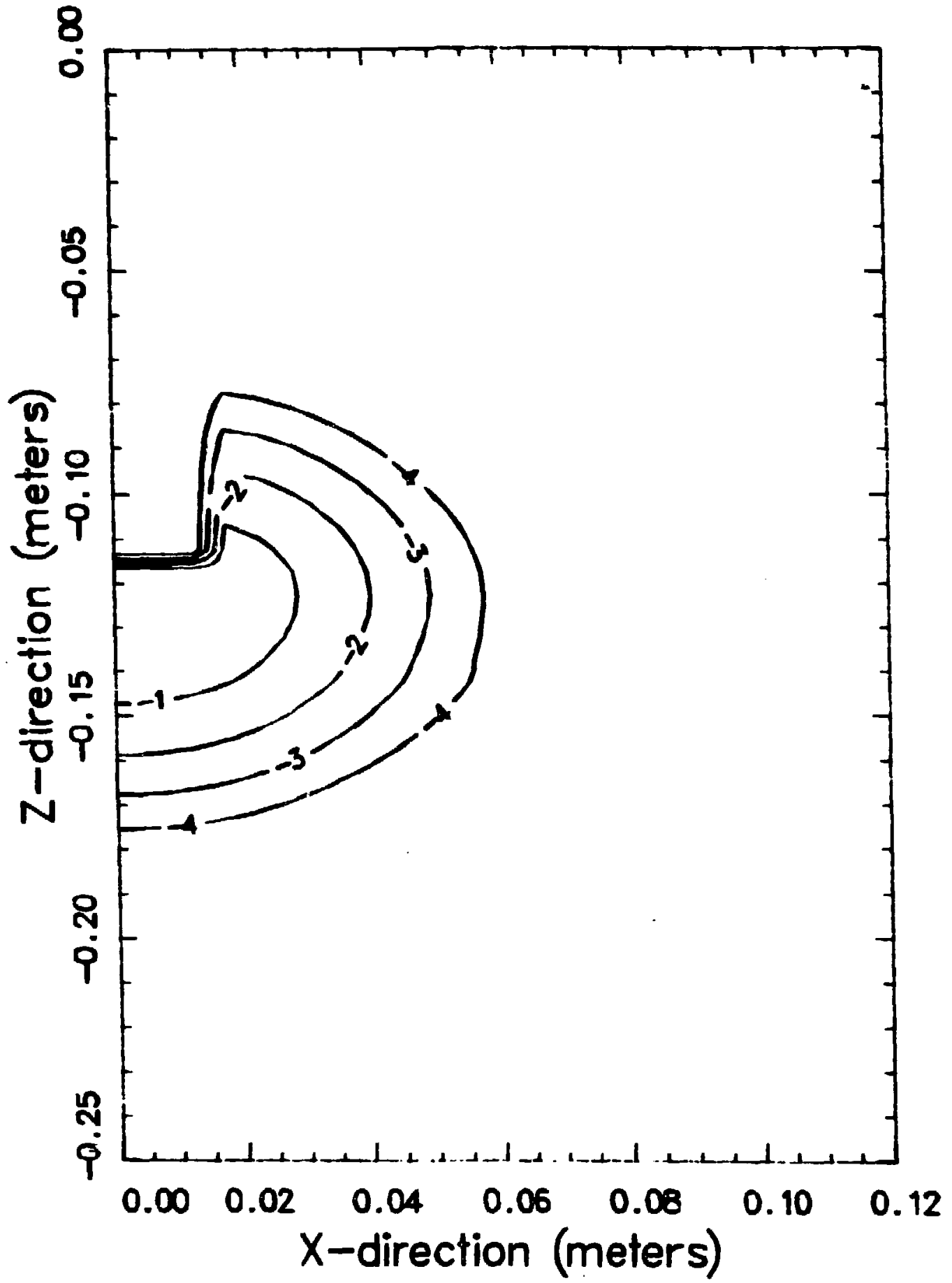

Fig. 10.

Continuous outflow boundary tracer-concentration profiles at 1.8 months calculated for horizontally fractured tuff of Calico Hills (zeolitized). Contours indicate the $\log$ of tracer concentration in $\mathrm{gm} /(\mathrm{cm})$. 


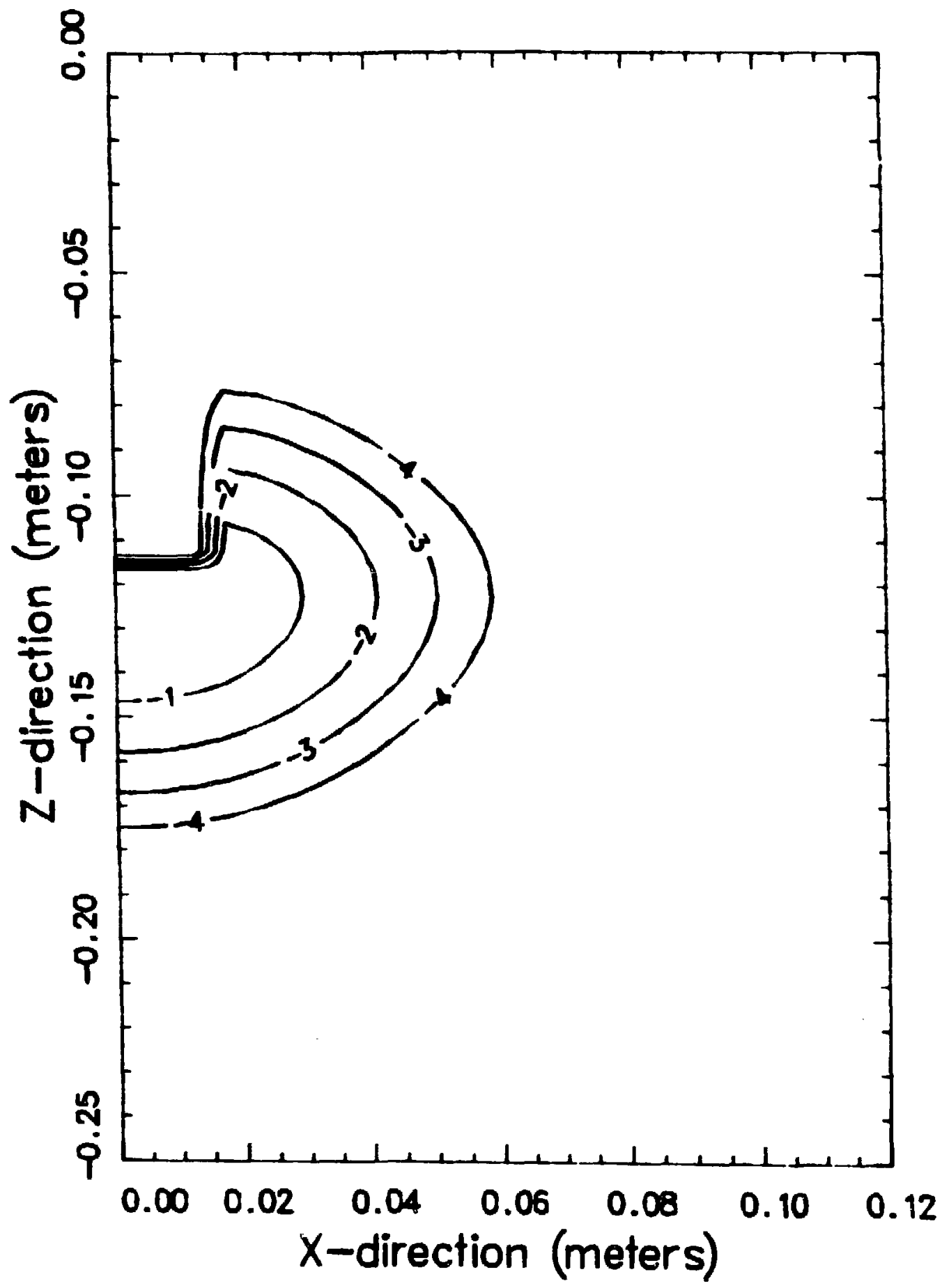

Fig. 11.

Continuous outflow boundary tracer-concentration profiles at 1.8 months calculated for unfractured tuff of Calico Hiljs (zeolitized). Contours indicate the $\log$ of tracer concentration in $\mathrm{gm} /(\mathrm{cm})$. 
TABLE IV. Tracer Concentration and Water Content in Fracture at Given Distance from Source Center

\begin{tabular}{|c|c|c|c|c|}
\hline & $\begin{array}{c}\text { Tracer } \\
\text { Concentration } \\
(\mathrm{g} / \mathrm{cm} \times 1000)\end{array}$ & $\begin{array}{l}\text { Water } \\
\text { Content }\end{array}$ & $\begin{array}{l}\text { Hor. Distance from } \\
\text { Source Center } \\
(\mathrm{cm})\end{array}$ & $\begin{array}{l}\text { Total } \\
\text { Time }\end{array}$ \\
\hline $\begin{array}{l}\text { Fractured } \\
\text { Unfractured }\end{array}$ & $\begin{array}{l}2.89 \\
1.15\end{array}$ & $\begin{array}{l}0.70 \\
0.707\end{array}$ & 3.25 & 18.6 days \\
\hline $\begin{array}{l}\text { Fractured } \\
\text { Unfractured }\end{array}$ & $\begin{array}{l}0.790 \\
0.442\end{array}$ & $\begin{array}{l}0.70 \\
0.705\end{array}$ & $4_{i} 25$ & $1.22 \mathrm{mo}$ \\
\hline $\begin{array}{l}\text { Fractured } \\
\text { Unfractured }\end{array}$ & $\begin{array}{l}2.00 \\
1.67\end{array}$ & $\begin{array}{l}0.70 \\
0.704\end{array}$ & 4.25 & $1.8 \mathrm{mo}$ \\
\hline $\begin{array}{l}\text { Fractured } \\
\text { Unfractured }\end{array}$ & $\begin{array}{l}0.509 \\
0.432\end{array}$ & $\begin{array}{l}0.70 \\
0.703\end{array}$ & 5.25 & $2.4 \mathrm{mo}$ \\
\hline $\begin{array}{l}\text { Fractured } \\
\text { Unfractured }\end{array}$ & $\begin{array}{l}1.10 \\
1.04\end{array}$ & $\begin{array}{l}0.70 \\
0.702\end{array}$ & 6.25 & $5.3 \mathrm{mo}$ \\
\hline
\end{tabular}

was found that the fracture had a noticeable effect on tracer dispersion during the first month after the tracer was released but negligible effect after two or more months time. The tracer concentration and water content in the fracture at a given horizontal distance from the source for various total elapsed times are summarized in Table IV.

The difference in the modeled runs was caused by the fluid velocity in the fracture. After 10 days the tracer-source water had drained out through the fracture, and the water content had come to equilibrium. For the unfractured case the water content had come to equilibrium in less than 18 days by diffusion through the matrix. The initial rush of water out the fracture caused the early tracer variation.

2. Modeling of Numerical Vertical Fracture Experiment. Simulations of water moving through devitrified tuff of the Topopah Spring Member with a vertical fracture were run to study the diffusion of a nonsorbing tracer with a diffusion coefficient in pure water of $1.0 \times 10^{-7} \mathrm{~cm}^{2} / \mathrm{s}$. As before, the diffusion coefficient was assumed to be independent of concentration, and a linear model resulted. The hydraulic properties for the Topopah Spring 
material were calculated from the same equations as were used for the Calico Hills rock in the previous experiment. For the Topopah Spring rock, the parameter values for $s_{w i}, K_{s_{-4}} \beta$, and a were taken as $0.0669,1.965 \times 10^{-6}$ darcy, 1.787 , and $0.519 \times 10^{-4}$, respectively. A porosity value of 0.094 was used in the calculations. The saturated permeability, $K_{s}$, for the fracture was assumed to be $1.1 \times 10^{-3}$ darcy.

The borehole dimensions, boundaries, and tracer-addition section were the same as in the horizontal fracture experiment. Grid spacings of $0.5 \mathrm{~cm}$ were set up in the $x$ and $z$ directions, except for the fracture, and radial symmetry was assumed. The vertical fracture was $0.01 \mathrm{~cm}$ wide and was $5.15 \mathrm{~cm}$ away from the borehole center. Matrix saturation, hydraulic properties of the tracer source, and tracer-source water content were the same as in the horizontalfracture experiment. Again at time $t=0$, a tracer concentration of $1.0 \mathrm{~g} / \mathrm{cm}^{3}$ was placed in the source region and allowed to diffuse into the matrix.

Tracer profiles for 1.5 days into the experiment are shown in Figs. 12 and 13. The first is a vertical slice through the center of the experiment with the left axis corresponding to the center of the borehole. The second is a slice along the fracture and normal to the first slice. In both figures there is symmetry about the left-hand axis. The spiked shape of the profile caused by the fracture can be seen in Fig. 12. Figure 14, showing the relative tracer velocities within the fracture at 1.5 days, shows that artificially high velocities have developed at the simulation boundaries. These are caused by radiation boundary conditions in the code. These high velocities in turn caused the numerical time step size to decrease to an unacceptably low level, and the run was terminated after five days into the experiment. The situation with the boundary conditions is being addressed.

\section{Summary of Vertical Fracture Experiment}

A numerical simulation was made to study tracer diffusion from a packedoff vertical borehole with a vertical fracture $0.01 \mathrm{~cm}$ wide, $5.15 \mathrm{~cm}$ away from the borehole center. The Topopah Spring hydraulic properties were used for the matrix and fracture. The source-water content was initially set at the saturated level, the source porosity was taken as 0.99 (boundary condition for tracer in water), and the tracer concentration assumed to be $1.0 \mathrm{~g} / \mathrm{cm}^{3}$. The rock had a uniform initial water content of $0.7 \mathrm{~cm}_{\text {water }}^{3} / \mathrm{cm}_{\text {voids' }}^{3}$ as in the earlier experiment. As expected, the water moved quickly through the fracture, creating a spiked tracer profile. Because of the high fluid 


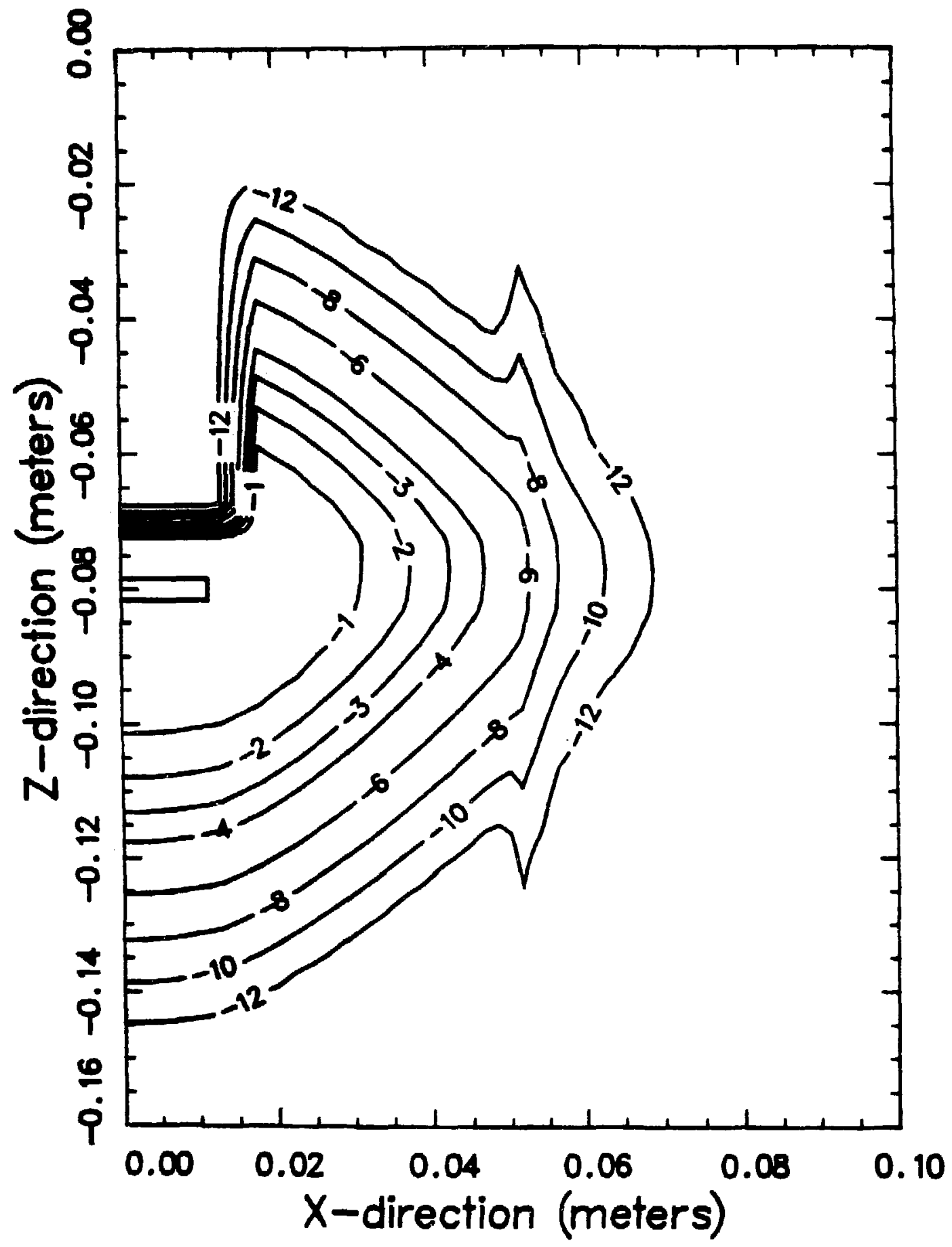

Fig. 12.

Continuous outflow boundary tracer-concentration profiles at 1.5 days for vertically fractured devitrified Topopah Spring Member. Contours indicate the log of tracer concentration in $\mathrm{gm} /(\mathrm{cm})$. 


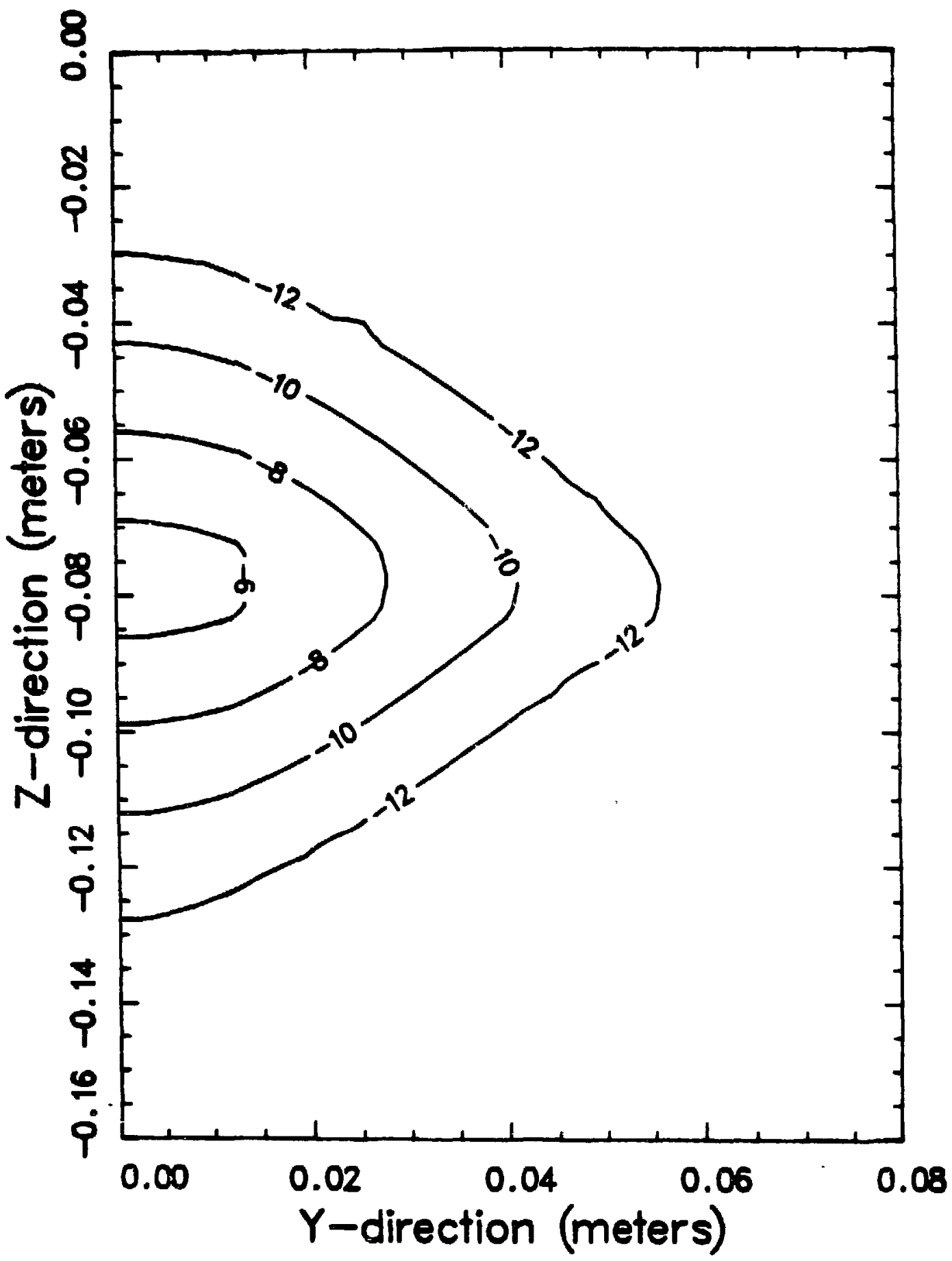

Fig. 13.

Tracer-concentration profiles at 1.5 days within the fracture of Fig. 12. This figure represents a vertical section perpendicular to Fig. 12 and along the fracture at $X=0.052$. Contours indicate the $10 \mathrm{~g}$ of tracer concentration in $\mathrm{gm} /\left(\mathrm{cm}^{3}\right)$. 


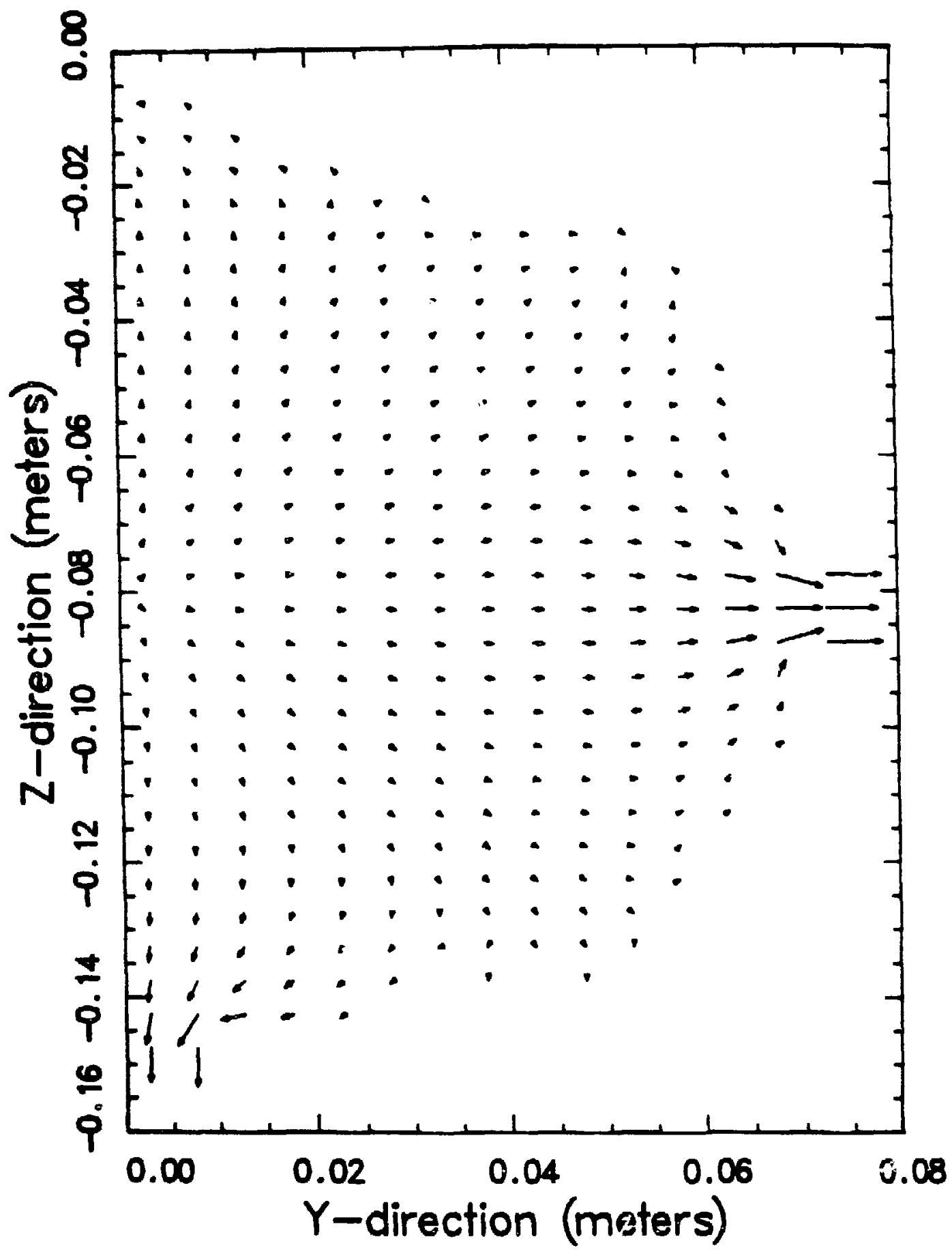

Fig. 14.

Tracer velocities at 1.5 days within the plane of the fracture in Fig. 13. Fracture is modeled as being $5.155 \mathrm{~cm}$ away from the injection point, along the $x$-direction. Arrow lengtins are proportional to velocity. 
velocities in the fracture, the time step in the numerical simulation was very sma 11, and the run was ended after simulating five days of transport.

B. Models of Tracer Diffusion in Topopah Spring and Calico Hills Materials

Two runs were made to study the differences in tracer diffusion in unfractured Topopah Spring and Calico Hills materials. The tracer was allowed to diffuse unimpeded through both matrices with uniform initial water contents of $0.7 \mathrm{~cm}_{\text {water }}^{3} / \mathrm{cm}^{3}$ voids for a period of one year. Throughout the test period, the Topopah Spring material exhibited higher tracer concentrations and a faster moving tracer front. The hydraulic properties for the two materials are very similar; the tracer concentration differences are a pure tracer diffusion effect caused by the great porosity difference between the two materials.

Modeling in Numerical Comparison of Diffusion Rates. As in the experiments reported above, diffusion of a nonsorbing tracer with a diffusion coefficient in water of $1.0 \times 10^{-7} \mathrm{~cm}^{2} / \mathrm{s}$ was simulated. The diffusion coefficient was assumed independent of concentration. Hydraulic properties were based on the equations presented above. The values of equation parameters used in the simulations were

$\begin{array}{lccc}K_{s} & \frac{\text { Topopah Spring }}{1.965 \times 10^{-6}} & \frac{\text { Calico Hills }}{2.068 \times 10^{-6}} \\ \text { swi }_{\text {B }} & 0.0669 & 0.0809 \\ \text { a } & 1.787 & 1.489 \\ \text { E } & 0.519 \times 10^{-4} & 0.364 \times 10^{-4} \\ & 0.094 & 0.33\end{array}$

The Dorehole dimensions and boundary conditions were the same as used in the experiments described above, as were the conditions of the source water and the tracer concentration at time $t=0$. Grid spacings of $0.5 \mathrm{~cm}$ were set up in the $x$ and $z$ directions, and radial symmetry was assumed. Tracer concentrations were followed in the two materials for 12 months.

The tracer concentrations and water contents at particular horizontal distances from the source center are shown for different times in Table $V$. The table shows that the water contents for the two materials do not differ 
TABLE V. Tracer Concentration and Water Content in Topopah Spring and Calico Hills Experiments

\begin{tabular}{|c|c|c|c|c|}
\hline & $\begin{array}{c}\text { Tracer } \\
\text { Concegntration } \\
\left.\left(\mathrm{g} / \mathrm{cm}^{2}\right) \times 1000\right)\end{array}$ & $\begin{array}{l}\text { Wa ter } \\
\text { Content }\end{array}$ & $\begin{array}{l}\text { Hor. Distance From } \\
\text { Source Center } \\
(\mathrm{cm})\end{array}$ & $\underset{\text { (mo) }}{\text { Total Time }}$ \\
\hline $\begin{array}{l}\text { Calico Hills } \\
\text { Topopah Spring }\end{array}$ & $\begin{array}{l}1.96 \\
11.4\end{array}$ & $\begin{array}{l}0.709 \\
0.709\end{array}$ & 4.75 & $\begin{array}{l}1.93 \\
1.92\end{array}$ \\
\hline $\begin{array}{l}\text { Calico Hills } \\
\text { Topopah Spring }\end{array}$ & $\begin{array}{l}1.39 \\
5.68\end{array}$ & $\begin{array}{l}0.709 \\
0.709\end{array}$ & 5.75 & $\begin{array}{l}3.81 \\
3.80\end{array}$ \\
\hline $\begin{array}{l}\text { Calico Hills } \\
\text { Topopah Spring }\end{array}$ & $\begin{array}{l}1.84 \\
5.90\end{array}$ & $\begin{array}{l}0.708 \\
0.708\end{array}$ & 6.25 & $\begin{array}{l}5.73 \\
5.72\end{array}$ \\
\hline $\begin{array}{l}\text { Calico Hills } \\
\text { Topopah Spring }\end{array}$ & $\begin{array}{l}1.75 \\
4.68\end{array}$ & $\begin{array}{l}0.700 \\
0.708\end{array}$ & 7.25 & $\begin{array}{l}9.51 \\
9.53\end{array}$ \\
\hline $\begin{array}{l}\text { Calico Hills } \\
\text { Topopah Spring }\end{array}$ & $\begin{array}{l}1.76 \\
4.39\end{array}$ & $\begin{array}{l}0.700 \\
0.707\end{array}$ & 7.75 & $\begin{array}{l}11.97 \\
11.97\end{array}$ \\
\hline
\end{tabular}

greatly. This was to be expected; the hydraulic properties for the Topopah Spring and Calico Hills materials are similar. The porosities are not, however. For this reason, the tracer moves faster in the Topopah Spring Member, and concentrations are several times higher in the Topopah Spring material at any given time. The differences in tracer concentrations are not as obvious on the figures because the concentrations there are depicted in exponential gradations. It requires a close comparison of Figs. 15 and 16, typical plots of the concentration profiles, to discern the difference. 


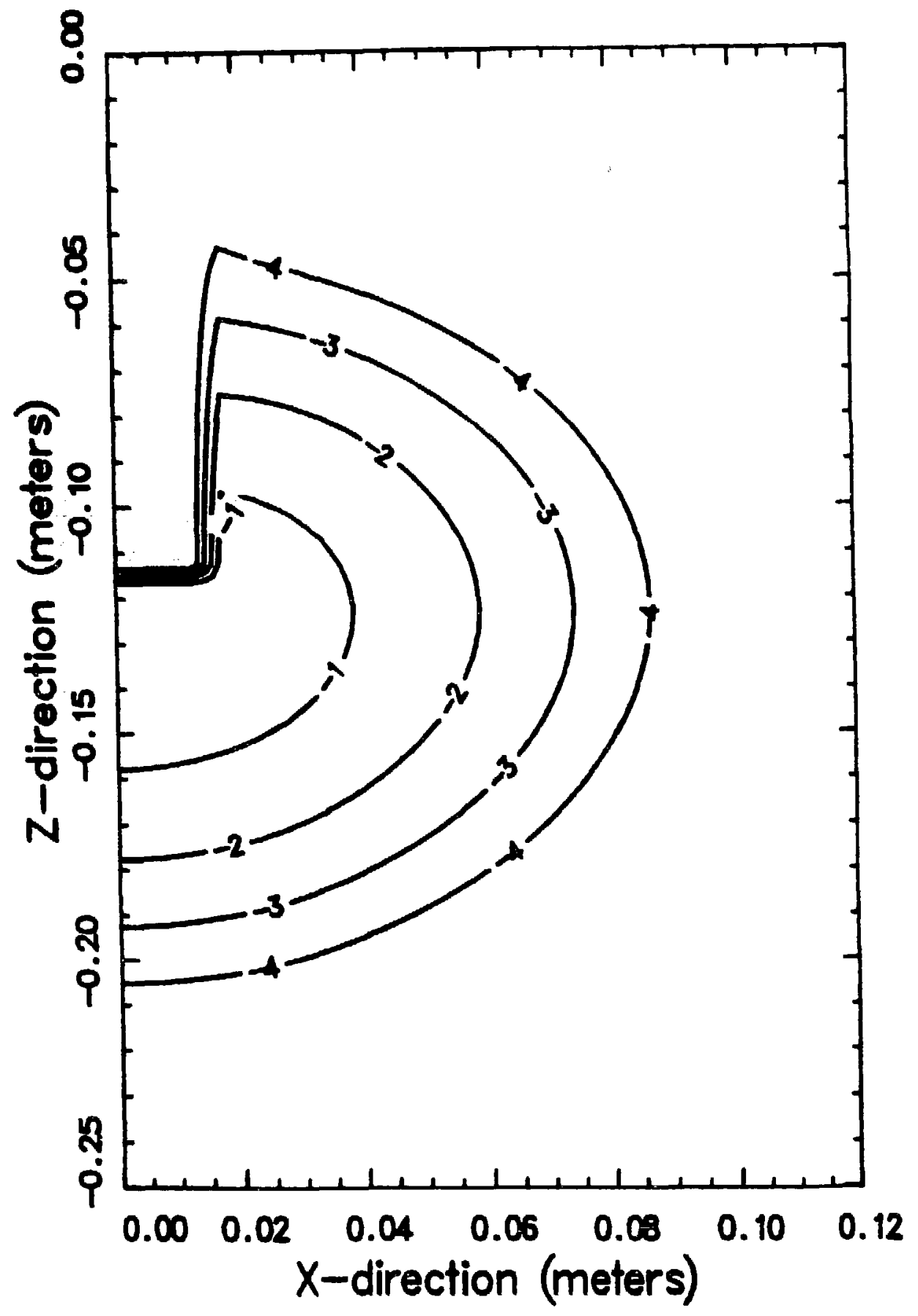

Fig. 15.

Tracer-concentration profiles at 5.7 months calculated for diffusion in unfractured devitrified Topopag Spring material. Contours indicate the log of tracer concentration in $\mathrm{gm} /(\mathrm{cm})$. 


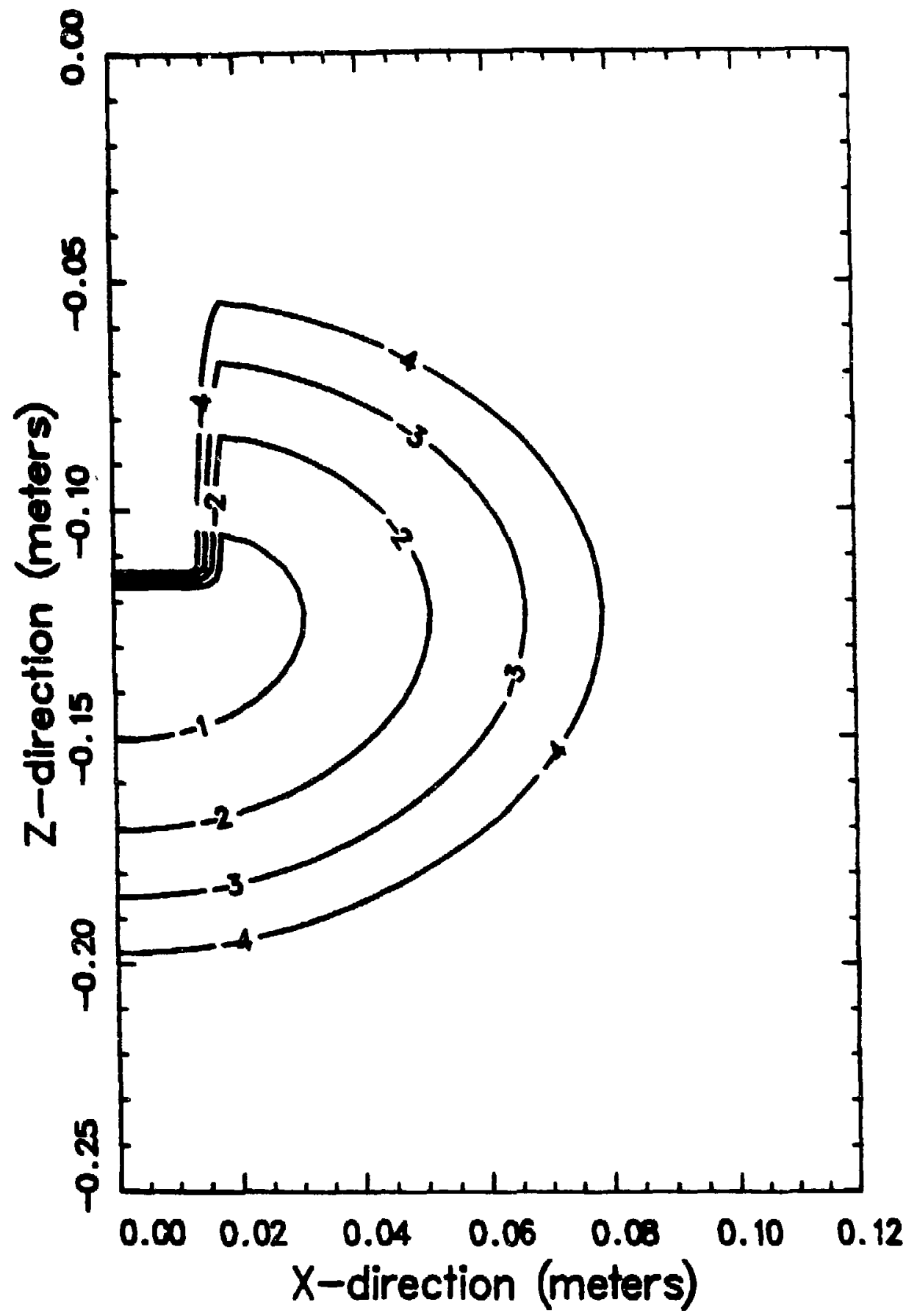

Fig. 16.

Tracer-concentration profiles at 5.7 months calculated for diffusion in unfractured zeolitized $\mathrm{CalicO}_{3} \mathrm{Hills}$ material. Contours indicate the $\mathrm{log}$ of tracer concentration in $\mathrm{gm} /\left(\mathrm{cm}^{3}\right)$. 
APPENDIX : GEOCHEMICAL RETARDATION IN THE HOST ROCK AND SURROUNDING UNITS--ANTICIPATED CONDITIONS

Through the use and application of numerical models, the data on sorption properties, matrix diffusion, flow rates (advection), radioactive decay, collolds speciation, and precipitation and dissolution can be synthesized with numerical models. Numerical models use the data concerning the processes as input and then calculate the total radionuclide transport and retardation through Yucca Mountain.

Currently avallable computer models can account for most of the known physical and geochemical transport processes (advection, diffusion, dispersion, matrix flow, fracture flow, and equilibrium sorption). More complex geochemical processes, such as speciation, dissolution and precipitation, and colloid formation have only very recently been incorporated into transport models. One model that can be used to simulate the transport of radionuclides from trie repository to the water table is TRACR3D (Travis, 1984; Perkins et a1., .985). As an example of model calculations under anticipated conditions, the transport of technetium-99 and uranium-238 was calculated. The processes assumed to affect transport in this example are advection, sorption, dispersion, matrix diffusion, and radioactive decay.

The relative importance of these processes is shown in Figs. A-1a, $A-1 b, A-2 a$, and A-2b. Figures A-1a and A-1b show the results of TRACR3D calculations after a 10,000-yr pulse of technetium-99 is introduced into a uniform vertical flow field of (1) $4.5 \mathrm{~mm} / \mathrm{yr}$ and (2) $0.5 \mathrm{~mm} / \mathrm{yr}$. The normalized mass flux entering the water table is plotted against time. The expected flux has been shown to range from 0.1 to $4.5 \mathrm{~mm} / \mathrm{yr}$ (Montazer and Vilson, 1984). If simple advection is the only transport process operating, the technetium-99 pulse will arrive at the water table without attenuation (the square pulses). Technetium-99 has a long half-life and Is only slightly sorbed onto the Yucca Mountain tuffs. Dispersion will be an important attenuating mechanism (by spreading out the pulse and reducing amplitude) followed by matrix diffusion. In the calculations, a dispersivity of $10 \mathrm{~cm}$ was used. Comparison of Figs. A-1a and A-1b show the magnitude of this effect. So, even where a small dispersivity is used, attenuation occurs. Also, in Fig. A-lb for the case of a slower flow rate, dispersion has a greater effect in attenuating the pulse because of the longer travel time. Therefore, for a conservative, nonsorbing radionuclide such as technetium-99, a slower flow rate will result in a longer travel time to the water table and a more attenuated, broadened pulse.

Figures $A-2 a$ and $A-2 b$ show the effects of sorption, dispersion, and diffusion on the transport of uranium-238. Again a 10,000-yr pulse is introduced in a uniform vertical flow field of (1) $4.5 \mathrm{~mm} / \mathrm{yr}$ and (2) 0.5 
mm/yx. Uranium-238 adsorbs readily to the Yucca Kountain tuffs. In Fig. A-2a (with the larger flow rate) sorption, dispersion, and diffusion act to delay the arrival of the peak by a factor of 10 and decrease the peak concentration by almost a factor of 10 . When the flow rate is decreased as In Fig. A-2b, sorption, dispersion, and diffusion act to delay the arrival of the peak to the water table by a factor of 200 and decrease the peak concentration by more than a factor of 100 .

It has been shown in this example calculation that under anticipated conditions the combined processes of sorption, dispersion, and diffusion have a significant effect on the transport of sorbing and nonsorbing radionuclides. Therefore, it is extremely important that these processes and their relative parameter values are well defined. As the processes and their relative parameter values become updated, more calculations similar to the example given above will be done to investigate the sensitivity of radionuclides transport to sorption, dispersion, and diffuston. 


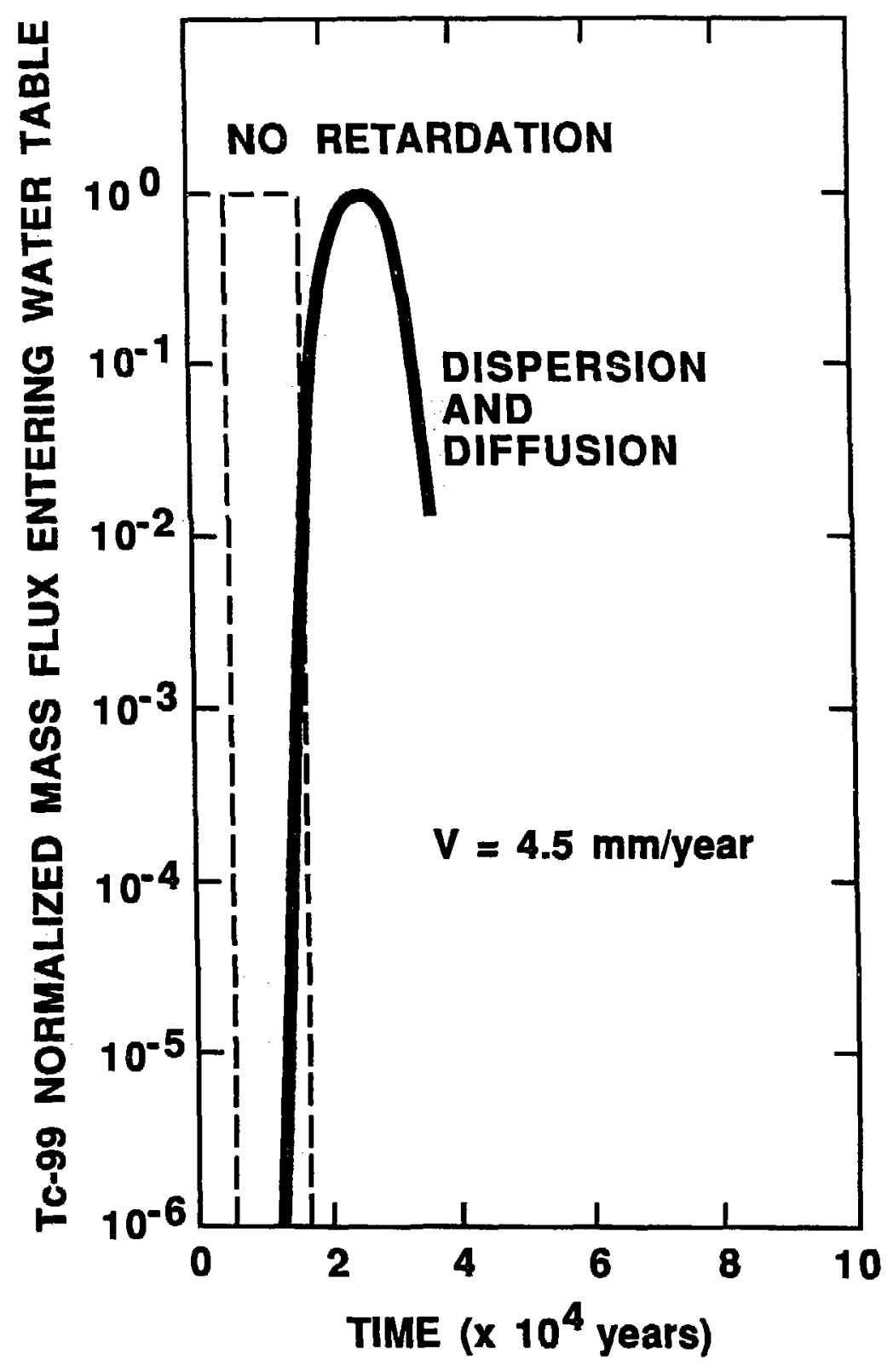

Fig. A-1a. The movement of a 10,000-yr pulse of technetium-99 for $\mathrm{V}=4.5 \mathrm{~mm} / \mathrm{yr}$. 


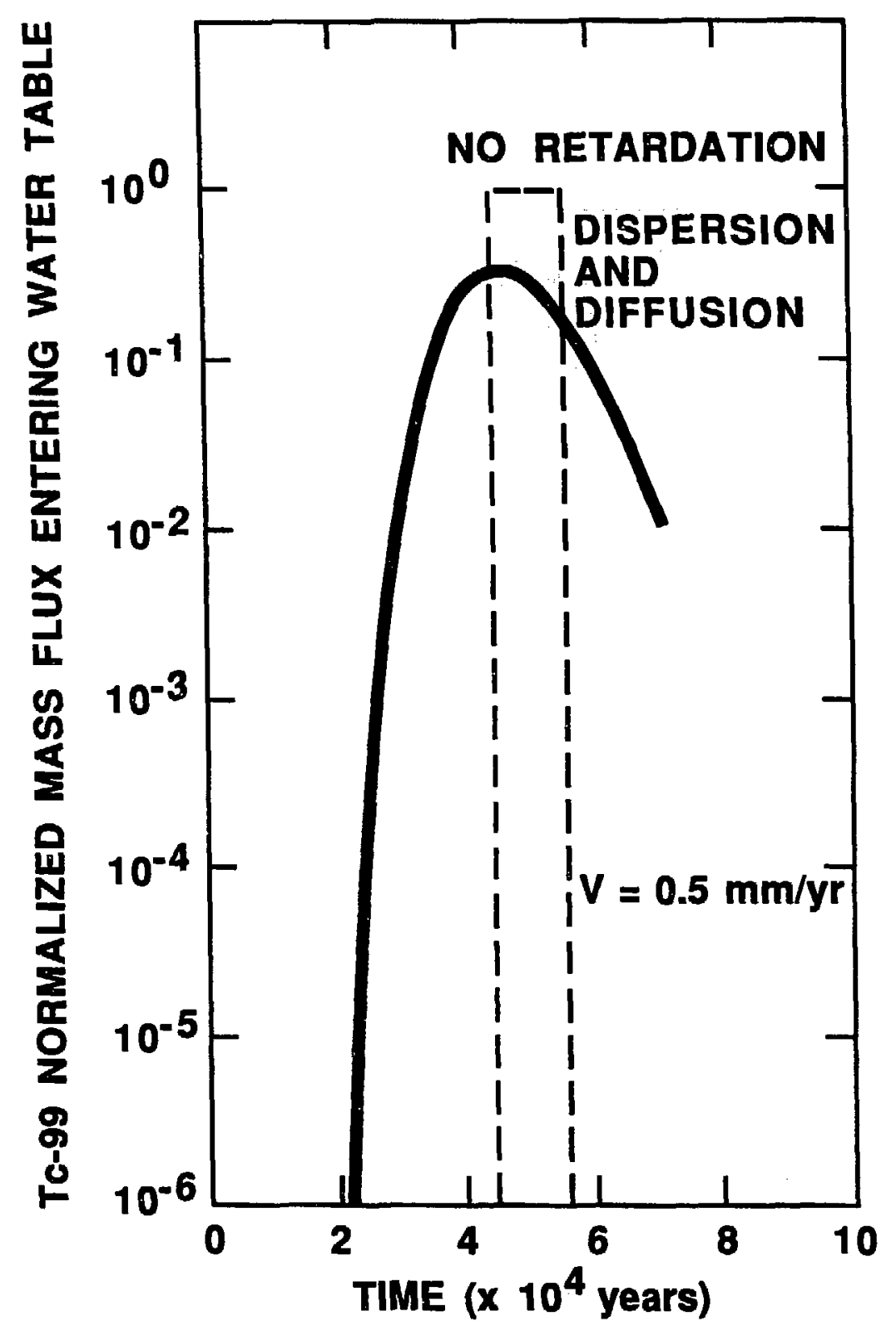

Fig. A-1b. The movement of a 10,000-yr pulse of technetium-99 for $V=0.5 \mathrm{~mm} / \mathrm{yr}$. 


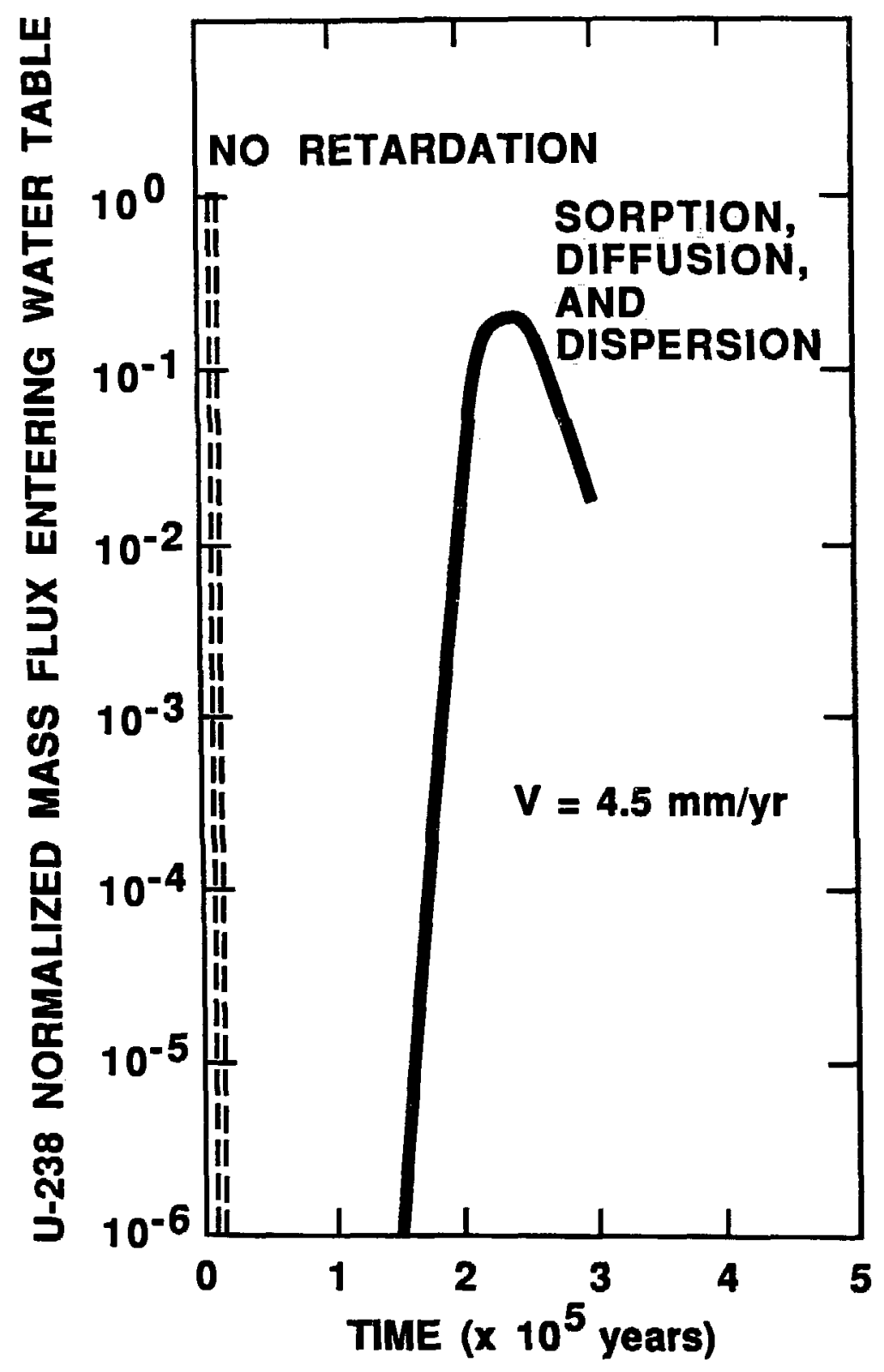

Fig. A-2a. Uranium-238 normalized mass flux entering water table for $V=4.5 \mathrm{mmi} y r$. 


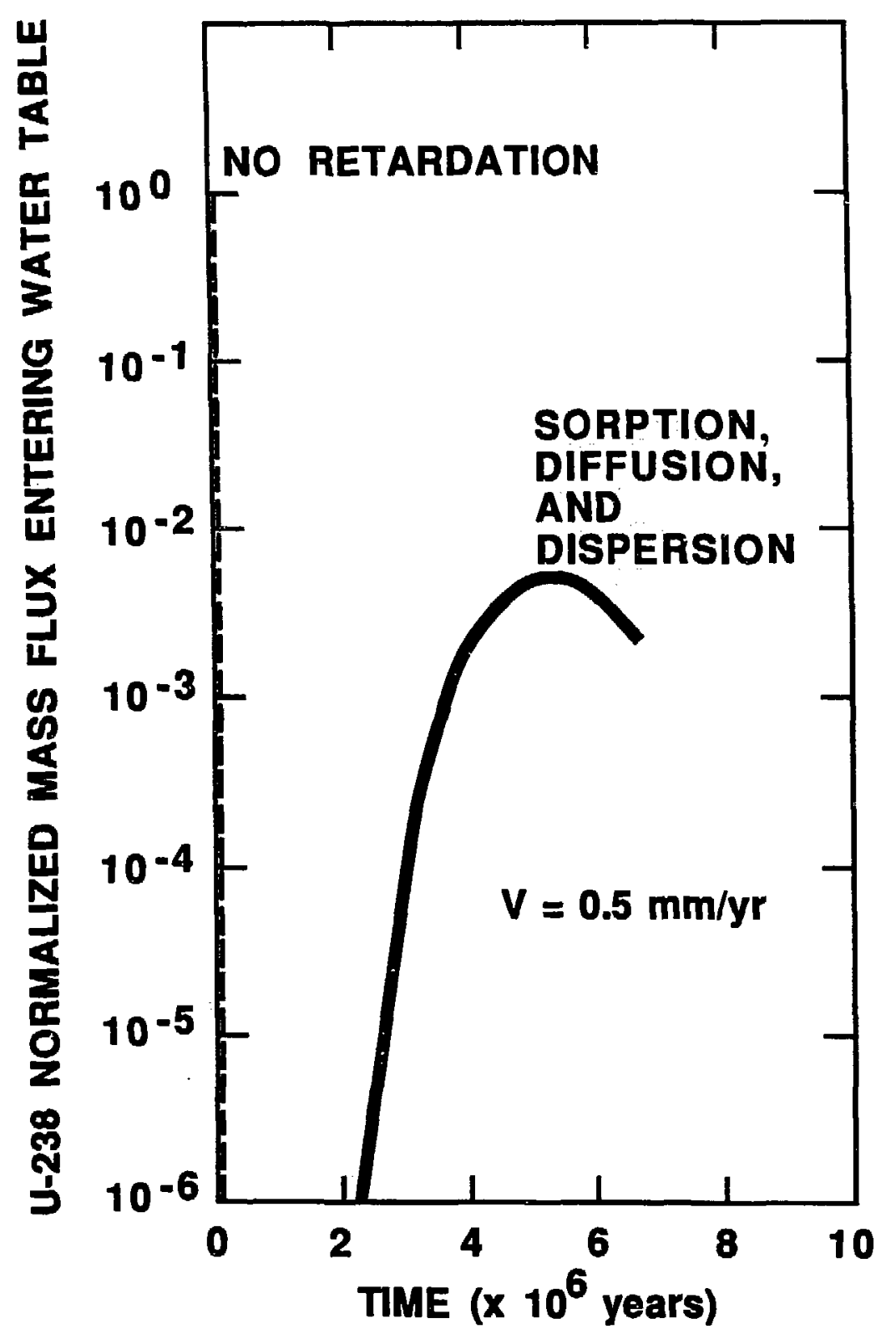

Fig. A-2b. Uranium-238 normalized mass flux entering water table for $V=0.5 \mathrm{~mm} / \mathrm{yr}$. 


\section{REFERENCES}

Bish, D. L.. "Effects of Exchangeable Cation Composition on the Thermal Expansion/Contraction of Clinoptilolite," Clays and Clay Miner., $\underline{32}$, $444-452(1984)$.

Bish, D. L., and R. E. Semarge, "Miner.logic Variations in a Silicic Tuff Sequence: Evidence for Diagenetic and Hydrothermal Reactions," 19 th Annual Clay Minerals Society Meetins, Hilo, Hawaii (Abstract), p. 42 (1982).

Bish, D. L., and D. T. Vaniman, "Mineralogic Summary of Yucca Mountain, Nevada," Los Alamos National Laboratory report LA-10543-MS (October 1985).

Bish, D. L., A. E. Ogard, and D. T. Vaniman, "Mineralogy-Petrology and Groundwater Chemistry of Yucca Mountain Tuffs," Materials Research Society Symposia Proceedings, 26, 283-291 (1984).

Byers, F. M., Jr., "Petrographic Variation of Topopah Spring Tuff Matrix with Depth (Stratigraphic Level), Drill Hole USW G-4, Yucca Mountain, Nevada," Los Alamos National Laboratory report LA-10561-MS (Decemb,r 1985).

Caporuscio, F., D. Vaniman, D. Bish, D. Broxton, B. Arney, G. Heiken, F. Byers, R. Gooley, and E. Semarge, "Petrologic Studies of Drill Cores USW-G2 and UE25b-1H, Yucca Mountain, Nevada," Los Alamos National Laboratory report LA-9255..MS (July 1982).

Carlos, B. A., "Minerals in Fractures of the Unsaturated Zone from Drill Core USW G-4, Yucca Mountain, Nye County, Nevada," Los Alamos National Laboratory report LA-10415-MS (May 1985).

Chung, F. H., "Quantitative Interpretation of X-Ray Diffraction Patterns of Mixtures. I. Matrix-Flushing Method for Quantitative Multicomponent Analysis," J. Appl. Crystallogr., 7, 519-525 (1974a).

Chung, F. H., "Quantitative Interpretation of X-Ray Diffraction Patterns of Mixtures. II. Adiabatic Principle of X-Ray Diffraction Analysis of Mixtures," J. Appl. Crystallogr., 7, 526-531 (1974b).

Lipman, P. H., R. L. Christiansen, and J. T. O'Connor, "A Compositionally Zoned Ash-Flow Sheet in Southern Nevada," U.S. Geological Survey Professional Paper 524-F, F1-F47 (1966).

Maldonado, F., and S. L. Koether, "Stratigraphy, Structure and Some Petrographic Features of Tertiary Volcanic Rocks at the USW G-2 Drill Hole, Yucca Mountain, Nye County, Nevada," U.S. Geological Survey Open-File Report 83-732, 83 p. (1983).

Montazer, P., and W. E. Wilson, "Conceptual Hydrologic Model of Flow in the Unsaturated Zone, Yucca Mountain, Nevada," U.S. Geological Survey Water-Resources Investigations Report 84-4345, 55 p. (1984). 
Mumpton, F. A., "A Reconnaissance Study of the Association of Zeolites with Mesothelioma Occurrences in Central Turkey," U.S. Geological Survey Open-File Report 79-954, 43 D. (1979).

Norris, A. E., F. M. Byers, Jr., and T. J. Merson, "Fran Ridge Horizontal Coring Summary Report, Hole UE-25h\#1, Yucca Mountain Area, Nye County, Nevada," Los Alamos National Laboratory report (in press).

Ogard, A. E., and J. F. Kerrisk, "Groundwater Chemistry Along Flow Paths Between a Proposed Repository Site and the Accessible Environment," Los Alamos National Laboratory report LA-10188-MS (November 1984).

Perkins, B., B. Travis, and G. DePoorter, "Validation of the TRACR3D Code for Soil Water Flow Under Saturated/Unsaturated Conditions in Three Experiments," Los Alamos National Laboratory report LA-10263-MS (January $1985)$.

Post, J. E., R. B. Von Dreele, and P. R. Buseck, "Symmetry and Cation Displacements in Hollandites: Structure Refinements of Hollandite, Cryptomelane and Priderite," Acta Crystallogr., B38, 1056-1065 (1982).

Rohl, A. H., A. M. Langer, G. Moncure, I. J. Selikoff, and A. Fischbein, "Endemic Pleural Disease Associated with Exposure to Mixed Fibrous Dust in Turkey," Science, 216, 518-520 (1982).

Sass, J. H., and A. H. Lachenbruch, "Preliminary Interpretation of Thermal Data from the Nevada Test Site," U.S. Geological Survey Open-File Report 82-973, 30 p. (1982).

Scott, R. B., and M. Castellanos, "Stratigraphic and Structural Relations o: Volcanic Rocks in Drill Holes USW GU-3 and USW G-3, Yucca Mountain, Nye County, Nevada," U.S. Geological Survey Open-File Report 84-491, 121 D. (1984).

Smyth, J. R., "Zeolite Stability Constraints on Radioactive Waste Isolation in Zeolite-Bearing Volcanic Rocks," J. Geol., 90, 195-201 (1982).

Travis, B. J., S.W. Hodson, E. R. Nuttall, T. L. Cook, and R. S. Rundberg, "Numerical Simulation of Flow and Transport in Fractured Tuff," Materials Research Society Symposia Proceedings, 26, 1039-1046 (1984).

Turner, S., and P. R. Buseck, "Manganese Oxide Tunnel Structures and Their Intergrowths," Science, $203,456-458$ (1979).

U.S. Department of Energy, "Draft Environmental Assessment, Yucca Mountain Site, Nevada Research and Development Area, Nevada," U.S. Department of Energy report, Washington, D.C. (1984).

Vaniman, D., D. Bish, D. Broxton, F. Byers, G. Heiken, B. Carlos, E. Semarge, F. Caporuscio, and R. Gooley, "Variations in Autnigenic Mineralogy and Sorptive Zeolite Abundance at Yucca Mountain, Nevada, Based on Studies of Drill Cores USW GU-3 and G-3," Los Alamos National Laboratory report LA-9707-MS (June 1984). 
Wadsiey, A. D., "The Crystal Structure of Psilomelane $\left(\mathrm{Ba}_{3} \mathrm{H}_{2} \mathrm{O}\right)_{2} \mathrm{Mn}_{5} \mathrm{O}_{10}$, Acta Crystallogr., 6, 433-438 (1953).

Wol fsberg, K., D. T. Vaniman, and A. E. Ogard, "Research and Development Related to the Nevada Nuclear Waste Storage Investigations, January 1 March 31, 1983," Los Alamos National Laboratory report LA-9793-PR (June 1983). 